\title{
5. EOCENE TO MIOCENE OCEANOGRAPHIC AND PROVENANCE CHANGES IN A SEQUENCE STRATIGRAPHIC FRAMEWORK: BENTHIC FORAMINIFERS OF THE NEW JERSEY MARGIN ${ }^{1}$
}

\author{
Miriam E. Katz ${ }^{2}$ and Kenneth G. Miller 2,3
}

\begin{abstract}
Drilling on the New Jersey continental slope and rise provides an Eocene bathyal to abyssal depth transect and an Oligocene to Miocene bathyal transect that allow the calibration of benthic foraminiferal abundance changes to independent depth estimates through time. New Jersey Transect benthic foraminiferal faunal changes reflect global, regional, and local influences and provide constraints on paleobathymetry and sediment provenance.

The New Jersey Transect yields cosmopolitan Eocene deep-water benthic foraminiferal faunas. Early to middle Eocene bathyal biofacies are characterized by Lenticulina spp., Alabamina wilcoxensis, and Osangularia spp., whereas coeval abyssal locations contain a deeper Nuttallides truempyi-dominated biofacies. A late middle Eocene shift to a bathyal biofacies dominated by Osangularia spp., Bulimina alazanensis, and Pullenia bulloides reflects a global event that affected bathyal and abyssal sites. However, we lack an abyssal record to evaluate the full regional impact of this global event. Late Eocene bathyal faunas on the New Jersey Transect contain high abundances of Bulimina alazanensis (up to 50\%), similar to peak B. alazanensis abundances reported from other Atlantic locations. We speculate that this uniform biofacies indicates that circum-Atlantic and Gulf of Mexico sites were ventilated by similar intermediate to upper deep-water masses in the late Eocene.

A cosmopolitan Lenticulina spp.-dominated biofacies prevailed in the Oligocene to early Miocene bathyal zone; polymorphinids and A. wilcoxensis were common secondary components of this biofacies. A Uvigerina hispida-B. alazanensis-dominated biofacies characterized the middle Miocene. A coeval increase in Uvigerina spp.-dominated faunas occurred in the Gulf of Mexico, indicating that this increase may be regional in extent. The shift from the Lenticulina spp.-dominated biofacies to the Uvigerina hispida-B. alazanensis-dominated biofacies may be the regional expression of a global late early to early middle Miocene benthic foraminiferal turnover event and associated abundance changes.

Oligocene to Miocene benthic foraminiferal biofacies changes at the slope sites exhibit sequence stratigraphic variations: (1) downslope-transported shelf taxa above several sequence boundaries (this may represent the slope expression of the shelf lowstand systems tracts) and in the upper parts of several sequences (within the slope equivalent of the shelf highstand systems tracts); (2) a preponderance of $U$. proboscidea occurs in the lower parts of several sequences (this may represent in situ biofacies within the slope expression of the lowstand systems tracts); (3) higher abundances of Stilostomella spp. occur in the upper parts of several sequences (this may represent the slope equivalent of the highstand systems tracts); and (4) and higher abundances of $M$. pompilioides span several sequence boundaries. We tentatively interpret the sections immediately above sequence boundaries as correlative to the lowstand systems tracts on the shelf. These sections contain predominantly in situ faunas with minor abundances of transported benthic foraminifers ( $<10 \%$ of the total fauna). Minor abundances of transported benthic foraminifers reappear in the upper parts of several sequences, and may reflect minor shedding of shelf sediments during highstand systems tracts progradation on the shelf.

Sedimentation in the early middle Miocene and older intervals was dominated by pelagic settling at our slope sites (as it is today), and there is little benthic foraminiferal evidence for widespread downslope transport prior to the middle middle Miocene at our sites. In the Leg 150 region of the New Jersey slope, a dramatic change in the dominant mode of sedimentation occurred between Reflectors $\mathrm{m} 3(13.5 \mathrm{Ma})$ and $\mathrm{m} 2(12.5 \mathrm{Ma})$. This change is indicated by (1) a major increase in downslope transport of neritic (shelf) species; (2) dramatically increased sedimentation rates ( $>60 \mathrm{~cm} / \mathrm{yr}$ ); (3) increased terrigenous input; (4) submarine channel cutting; (5) high terrestrial carbon input; and (6) mobilization of biogenic carbonate to form diagenetic nodules. Transported benthic foraminifers dominate the upper middle Miocene to Pleistocene section of the slope cores, reflecting increased sediment supply due to the progradation of clinoforms that progressed from $90 \mathrm{~km}$ landward of Site 903 in the early Miocene to $\sim 60 \mathrm{~km}$ landward in the middle Miocene to less than $20 \mathrm{~km}$ landward in the Pleistocene.
\end{abstract}

\section{INTRODUCTION}

One of the primary goals of Ocean Drilling Program (ODP) Leg 150 was to evaluate the nature of slope sedimentation and its response to global sea-level changes (Miller and Mountain, 1994). This evaluation involves reconstructing sediment provenance changes and changes in dominant depositional processes (e.g., gravity flows vs. hemipelagic settling) on both long-term (10 m.y.) and shorter term

'Mountain, G.S., Miller, K.G., Blum, P., Poag, C.W., and Twichell, D.C. (Eds.), 1996. Proc. ODP, Sci. Results, 150: College Station, TX (Ocean Drilling Program).

${ }^{2}$ Lamont-Doherty Earth Observatory of Columbia University, Palisades, NY 10964. U.S.A.mkatz@1deo.columbia.edu

Department of Geological Sciences, Rutgers University, Piscataway, NJ 088551179, U.S.A. kgm@rci.rutgers.edu
( 1 m.y.) scales. Although changes in provenance are often evaluated using sedimentological criteria (e.g., Mazzullo, 1986), benthic foraminifers also provide reliable tracers of neritic sediment sources for continental slope deposits (Brunner and Culver, 1992). For example, benthic foraminifers can be especially useful in sorting out the origins of multiple-source materials on the lower slope and upper rise (e.g., McHugh et al., this volume).

Previous foraminiferal studies demonstrate that the dominant pattern of sedimentation on the New Jersey continental slope today is pelagic settling (Miller and Lohmann, 1982; Streeter and Lavery, 1982; Christensen and Miller, 1991) with minimal evidence for downslope transport processes. Observations made from submersibles also indicate that most of the middle slope is draped with (hemi-)pelagic muddy oozes in the Carteret Canyon area (K.G. Miller, pers. comm., 1989). In contrast, widespread erosion characterized 
the New Jersey slope in the past (Poag, Watts, et al., 1987); benthic foraminiferal studies show the downcore presence of transported material on the floors and southwestern walls of Lindenkohl and Carteret Canyons and on the crests of their southwestern walls (interfluves) (Christensen and Miller, 1991). Leg 150 drilling established that intervals of pervasive downslope transport were concentrated in Pleistocene glacial periods, although transported benthic foraminifers also dominated interglacial periods (Christensen et al., this volume). One of the topics addressed by Leg 150 is whether pre-Pleistocene intervals on the New Jersey slope were characterized by tranquil pelagic settling or dominated by downslope transport.

Benthic foraminifers also can be used to evaluate changes in source and depositional environments within sequences (i.e., stratigraphic sections bracketed by unconformities). Changes in neritic benthic foraminiferal biofacies have been used successfully to decipher sequences deposited on continental shelves (e.g., Miller et al., 1994; Olsson et al., 1987; Christensez et al., in press). However, no benthic foraminiferal biofacies model for slope sequences has been published, and it is unclear whether benthic foraminifers exhibit a predictable succession correlative to the classic systems tracts model (Posamentier et al., 1988). For example, are there (1) "lowstand systems tract" biofacies on the slope that are characterized by transported benthic foraminiferal biofacies; (2) "transgressive systems tract" biofacies characterized by benthic foraminifers more typical of pelagic settings; and/or (3) "highstand systems tract" biofacies characterized by benthic foraminifers typical of regions with high supply of terrigenous sediments? A sequence stratigraphic framework for the New Jersey slope was developed by tracing seismic reflectors from the shelf to four Leg 150 slope boreholes (e.g., Miller and Mountain, 1994), providing the opportunity to evaluate intrasequence and longer term changes on the slope using the benthic foraminiferal record.

Drilling on the New Jersey continental slope and rise by ODP Leg 150 (Sites 902, 903, 904, and 906; 811, 444, 1123, and $913 \mathrm{~m}$ water depth, respectively), Deep Sea Drilling Project (DSDP) Leg 95 (Sites 612 and 613, 1404 and $2323 \mathrm{~m}$ water depth, respectively; Poag, Watts, et al., 1987), and DSDP Leg 11 (Site 108, $1815 \mathrm{~m}$ water depth; Hollister, Ewing, et al., 1972), provides an Eocene bathyal to abyssal transect and an Oligocene to Miocene bathyal transect (Fig. 1; Table 1; see Miller and Katz 1987a, for locations of Sites 108, 390, and 613). Site 390 (DSDP Leg 44, $2665 \mathrm{~m}$ water depth; Benson, Sheridan, et al., 1978), drilled on the Blake Nose, is included in this study because it is an abyssal location in the same region as the New Jersey Transect. Similar depth transects have proven valuable for reconstructing age-depth changes through time (e.g., Katz and Miller, 1993). This transect approach provides an opportunity to evaluate Eocene to Miocene benthic foraminiferal abundance changes through depth and time on the New Jersey slope by calibrating them to independent depth estimates obtained from backtracking (Berger and Winterer, 1974) and backstripping (Steckler and Watts, 1982). In addition, the New Jersey Transect shows benthic foraminiferal faunal changes that reflect global, regional, and local influences and provide constraints on sediment provenance.

\section{METHODS \\ Benthic Foraminifers}

Samples were washed with sodium metaphosphate $(5.5 \mathrm{~g} / \mathrm{L})$ in tap water through a $63-\mu \mathrm{m}$ sieve and air-dried. Benthic foraminifers were picked from aliquots of the greater than $150-\mu \mathrm{m}$ size fraction and mounted on reference slides. We chose this fraction to be consistent with previous studies on this margin (e.g., Streeter and Lavery, 1981; Miller and Katz, 1987a) and the deep sea (e.g., Thomas, 1990). We avoid the $63-150-\mu \mathrm{m}$ size fraction preferred by some authors (e.g., Schröder et al., 1987) because of problems in identifying small taxa. While we lose information obtainaule from the $63-150-\mu \mathrm{m}$ size fraction, we gain information on larger taxa (i.e., in an aliquot picked from the $>63-\mu \mathrm{m}$ size fraction, many larger taxa are underemphasized while small, difficult to identify taxa are emphasized).

In general, 300-400 specimens were picked per sample. However, samples with as few as 85 specimens were used in the faunal analyses; samples that yielded too few specimens were omitted from analyses. Three hundred and nineteen samples were examined for this study (Table 1). Closely spaced samples (2-m sampling interval) from the m5 sequence at Sites 903 and 904 that were examined for intrasequence biofacies changes were not included in the multivariate analyses.

Stratigraphic control was obtained from planktonic foraminifers (Snyder et al., this volume), nannofossils (Aubry in Mountain, Miller, Blum, et al., 1994), and strontium isotope stratigraphy (Miller et al., this volume). Sample ages were assigned by interpolating between planktonic biostratigraphic datums and $\mathrm{Sr}$ isotope ages and by extrapolating where necessary (Table 2 ). The time scale of Berggren et al. (1985) was used to be consistent with shipboard studies and Mountain, Miller, Blum, et al. (1994). Cande and Kent (1992) made substantial revisions ( $>2 \mathrm{~m} . \mathrm{y}$. in some cases) to much of the Paleogene geomagnetic polarity time scale (GPTS). The boundary calibrations of chronostratigraphic units, zones, and isotopic correlations have only recently been calibrated to the GPTS (Berggren et al., 1995); in order to maintain consistency in view of a rapidly evolving time scale, Leg 150 participants decided to report ages based on the Berggren et al. (1985) geological time scale. Although the numerical ages presented here will change with the Berggren et al. (1995) time scale, the relative faunal patterns will remain the same.

Our identifications of most of the benthic foraminifers follow the taxonomy of van Morkhoven et al. (1986) and Tjalsma and Lohmann (1983). Our taxonomic base for most of the uvigerinids follows Boersma (1984). Not all species present were identified; for example, species of some common (Lenticulina, Oridorsalis, and Gyroidinoides) and some rare (Lagena, Fissurina, and Oolina) genera were not differentiated. We revised the taxonomy of Miller and Katz (1987a) for Sites $108,390,612$, and 613 to be consistent with the taxonomy of the Leg 150 samples (see Appendix).

We performed Q-mode principal components and varimax factor analyses on the relative abundance (percentage) data using modifications of programs provided by Lohmann (1980). The Q-mode principal components and varimax factor programs utilize a cosine-theta matrix, standardizing each sample to unit length. Each factor represents a unique benthic foraminiferal biofacies. Factor analysis of the New Jersey Margin samples reveals stratigraphically meaningful biofacies successions. We used factor analysis to identify trends in the benthic foraminiferal biofacies at Sites 902, 903, 904, and 906. We analyzed each site individually and then combined the data from Sites $902,903,904$, and 906 with Sites $108,390,612$, and 613 to form two data sets, the Eocene and the Oligocene to Miocene, to emphasize depth rather than age differences. However, there is virtually no Oligocene to middle Miocene section at the deeper Sites 108, 390, 612, and 613 ; therefore, the lowermost bathyal to abyssal depths are represented only for the Eocene. The Eocene data set consists of 96 samples and 114 taxa, and the Oligocene to Miocene data set consists of 102 samples and 104 taxa. We limited our data sets used in the factor analyses to samples that yielded primarily in situ biofacies.

We use "bubble plots" to display three-dimensional data (agepaleodepth-species data/factor analysis results) in two dimensions (e.g., Tjalsma and Lohmann, 1983; Katz and Miller, 1993). They are well suited for displaying (1) long-term (m.y.) trends in species data that often contain high-frequency signals (e.g., Milankovitch scale); and (2) data that have uncertainties in age (typically \pm 0.5 m.y.) or paleodepth (typically \pm several hundred meters). Bubble plots clearly show how benthic foraminiferal species abundances and biofacies have changed through time across a paleobathymetric range. Bubble size is proportional to each factor loading or species percentage. 
A

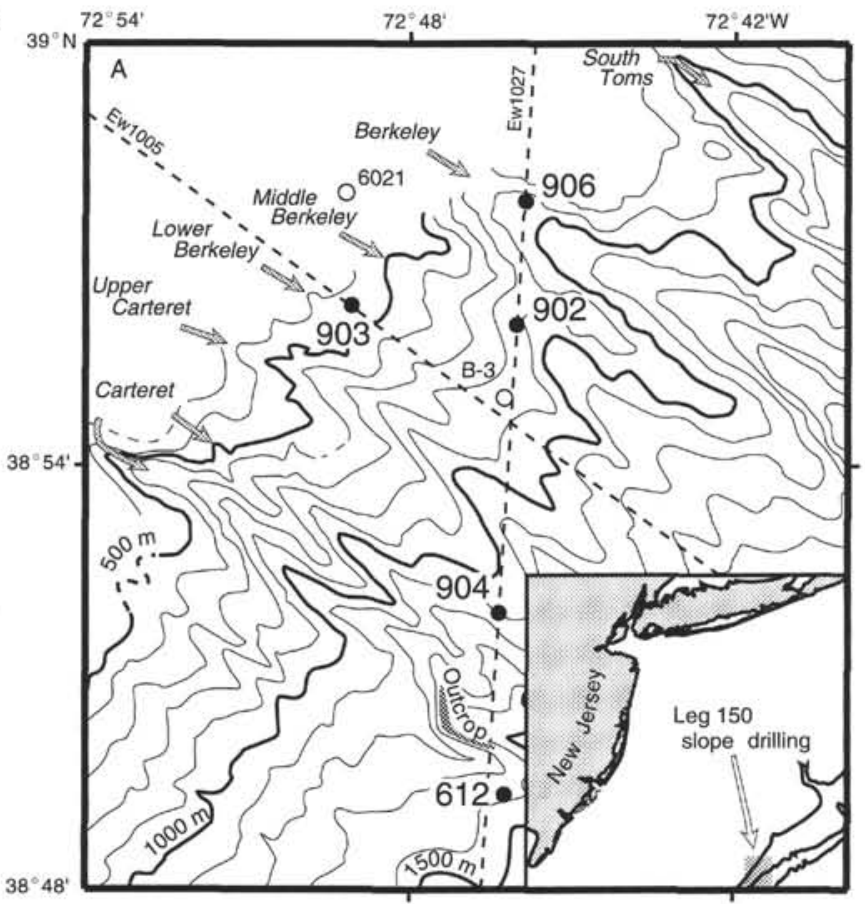

B

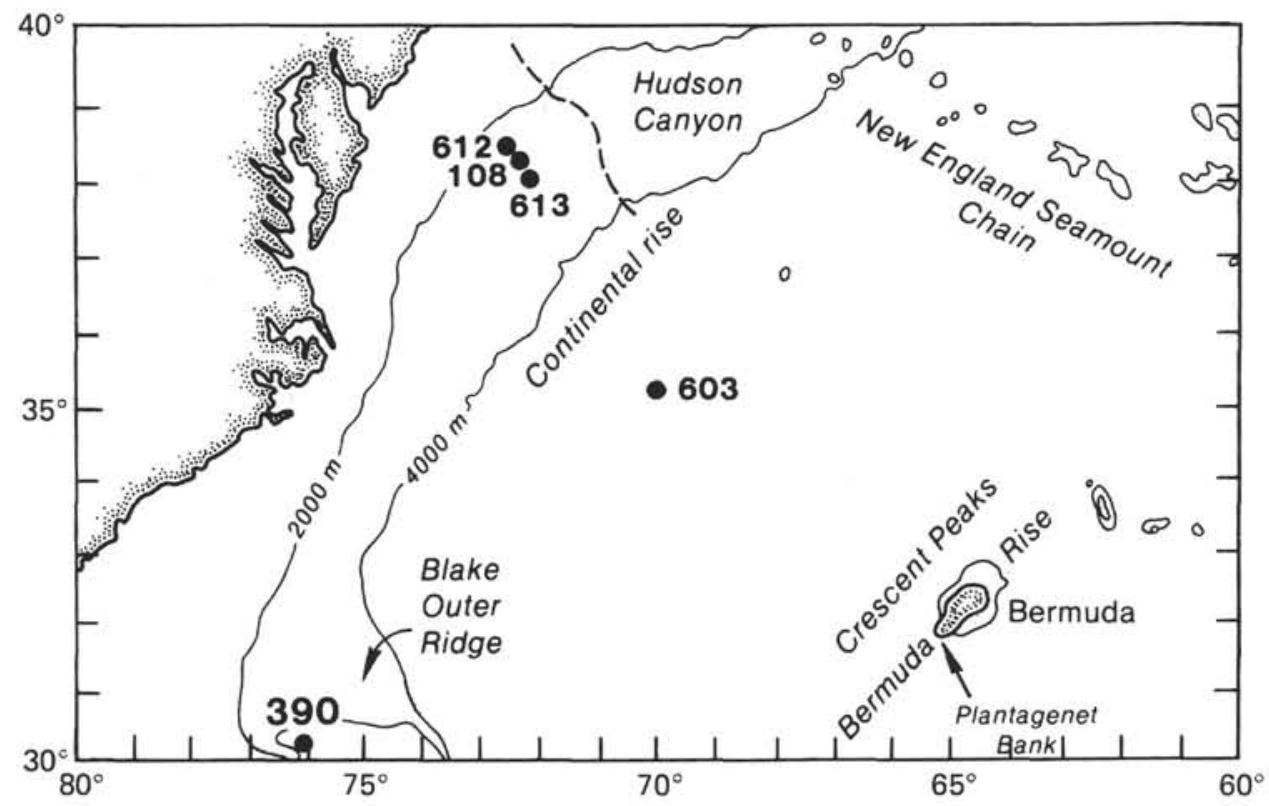

Figure 1. A. SeaBeam bathymetric location map of the middle continental slope (500-1500 m water depth) drilled by Leg 150 showing ODP Sites 902 , 903 , 904, and 906, and DSDP Site 612. SeaBeam data were collected by Atlantis II 120 and 124 and processed by W.B.F. Ryan and D. Twichell, unpubl. data, 1989 (after Mountain, Miller, Blum, et al., 1994). Ew1005 and Ew1027 are multichannel seismic profiles illustrated in Mountain, Miller, Blum, et al. (1994). B. Location map showing DSDP Sites 108, 390, 612, and 613 (after Miller and Katz, 1987a).

\section{Paleobathymetry}

Benthic foraminifers have been recognized for their usefulness in assessing paleobathymetry (e.g., Natland, 1933; Bandy, 1960), although it is clear that factors other than water depth control the distributions. For example, deep-sea benthic foraminiferal distributions are often associated with water mass (e.g., Streeter, 1973; Bremer and Lohmann, 1982), productivity (e.g., Thomas et al., 1995), or substrate (e.g., Miller and Lohmann, 1982), characteristics that may vary independently of water depth. Independent estimates of paleobathymetry (backtracking of Berger and Winterer, 1974; backstrip- ping of Steckler and Watts, 1982) provide calibrations for benthic foraminiferal abundance changes and species ranges through time across paleodepths (e.g., Tjalsma and Lohmann, 1983). Once faunal trends are calibrated using independent paleodepth estimates, benthic foraminiferal distributions can be used to evaluate paleodepths for sections lacking independent depth estimates.

The Eocene to Holocene sections at Sites 108, 612, 613, 902, 903, 904 , and 906 overlie very thick (>10 km) Jurassic-Holocene sediments and thinned (transitional) continental to oceanic crust (Grow and Sheridan, 1988). Thus, they cannot be rigorously backtracked using conventional age-subsidence curves (e.g., Berger and Winterer, 
Table 1. DSDP and ODP sites included in this study.

\begin{tabular}{cccccccc}
\hline Site & Location & $\begin{array}{c}\text { Present water } \\
\text { depth }(\mathrm{m})\end{array}$ & $\begin{array}{c}\text { Number of } \\
\text { samples }\end{array}$ & $\begin{array}{c}\text { No. of } \\
\text { samples in } \\
\text { analyses }\end{array}$ & $\begin{array}{c}\text { No. of taxa in } \\
\text { individual } \\
\text { analyses }\end{array}$ & $\begin{array}{c}\text { Backstripped } \\
\text { paleodepth } \\
(\mathrm{m})\end{array}$ & $\begin{array}{c}\text { Backtracked } \\
\text { paleodepth } \\
(\mathrm{m})\end{array}$ \\
\hline 108 & $38^{\circ} 48.27^{\prime} \mathrm{N}, 72^{\circ} 39.21^{\prime} \mathrm{W}$ & 1815 & 2 & 2 & n.a. & 1680 & 1650 \\
390 & $30^{\circ} 08.54^{\prime} \mathrm{N}, 76^{\circ} 06.74^{\prime} \mathrm{W}$ & 2665 & 5 & 5 & n.a. & & $2365-2425$ \\
612 & $38^{\circ} 49.21^{\prime} \mathrm{N}, 72^{\circ} 46.43^{\prime} \mathrm{W}$ & 1404 & 31 & 31 & n.a. & $1280-1305$ & $1320-1430$ \\
613 & $38^{\circ} 46.26^{\prime} \mathrm{N}, 72^{\circ} 30.43^{\prime} \mathrm{W}$ & 2323 & 11 & 7 & n.a. & $2200-2215$ & $2275-2310$ \\
902 & $38^{\circ} 56.08^{\prime} \mathrm{N}, 72^{\circ} 46.38^{\prime} \mathrm{W}$ & 811 & 41 & 41 & 108 & $790-830$ & $1050-1070$ \\
903 & $38^{\circ} 56.30^{\prime} \mathrm{N}, 72^{\circ} 49.03^{\prime} \mathrm{W}$ & 444 & 118 & 34 & 132 & $470-500$ & $790-935$ \\
904 & $38^{\circ} 51.81^{\prime} \mathrm{N}, 72^{\circ} 46.08^{\prime} \mathrm{W}$ & 1123 & 68 & 45 & 141 & $1025-1120$ & $1155-1215$ \\
906 & $38^{\circ} 57.90^{\prime} \mathrm{N}, 72^{\circ} 46.00^{\prime} \mathrm{W}$ & 913 & 43 & 31 & 109 & $870-930$ & $1075-1135$ \\
\hline
\end{tabular}

Note: n.a. $=$ not applicable.

1974), although we previously backtracked Sites 108, 612, and 613 (Miller and Katz, 1987a). We followed Miller and Katz (1987a) in computing a first-order paleodepth estimate by accounting for Airy loading and simple thermal subsidence in the "backtracking" form:

$$
\text { Paleodepth }=\text { Initial depth }-A+A \cdot \mathrm{e}^{(-t / \tau)}-S \text {, }
$$

where $t=$ basement age - age level considered; $\tau=$ empirical decay constant, $62.5 ; A=$ empirical scaling constant, -3650 ; and $S=$ the Airy correction, 0.66 - (basement depth - depth of level considered) (see Miller and Katz, 1987a).

We backtracked paleodepths assuming crustal ages of (1) $180 \mathrm{Ma}$ and $13 \mathrm{~km}$ of sediments for Sites 902, 903, 904, 906 (Mountain, Miller, Blum, et al., 1994) and 612 (Poag, 1985); (2) $180 \mathrm{Ma}$ and $10 \mathrm{~km}$ of sediments for Site 613 (Poag, 1985); (3) $180 \mathrm{Ma}$ and $11 \mathrm{~km}$ of sediments for Site 108 (Poag, 1985); and (4) $160 \mathrm{Ma}$ and $380 \mathrm{~m}$ of sediments for Site 390 (Benson, Sheridan, et al., 1978).

M. Steckler (pers. comm., 1995) rigorously "backstripped" Sites $108,612,613,902,903,904$, and 906, which lie on transitional continental crust. He used the method of Steckler et al. (1988), correcting for the effects of compaction, loading, and thermal subsidence, and the long-term sea-level change of Kominz (1984). M. Steckler (pers. comm., 1995) assumed an age of $185 \mathrm{Ma}$ for the crust with $12 \mathrm{~km}$ of sediment, and he used Airy isostasy. The differences between the backtracked and backstripped paleodepths primarily reflect the effects of decompaction taken into account in the backstripping method (Table 1). The backstripped paleodepth estimates were generally less than $150 \mathrm{~m}$ shallower than the backtracked paleodepth estimates for the deeper water sites $(108,613,612$, and 904). The shallower sites have thicker Pleistocene sections that need to be removed via backstripping in order to calculate reliable paleodepths. The effects of the thick Pleistocene sections are apparent in the greater differences between the backtracked and backstripped paleodepths at the shallower sites (Table 1). In this study, we use the backstripped paleodepths for all sites (except for Site 390, for which we used the backtracking method, which is applicable to normal oceanic crust with thin sediments) to evaluate benthic foraminiferal faunal trends through depth and time (Table 3 ).

We use the following bathymetric zones (e.g., van Morkhoven et al., 1986; Berggren and Miller, 1989): bathyal $=200-2000 \mathrm{~m}$ (upper: 200-600 m; middle: 600-1000 m; lower: $1000-2000 \mathrm{~m}$ ); and abyssal $=>2000 \mathrm{~m}$ (upper: $2000-3000 \mathrm{~m}$; lower: $>3000 \mathrm{~m}$ ).

\section{Sequence Stratigraphic Framework}

In order to evaluate benthic foraminiferal changes within sequences, the sequence boundaries must be located precisely. Sequence boundaries were located initially using seismic profiles (Miller and Mountain, 1994) that were correlated to the slope boreholes drilled by Leg 150 (summarized in Mountain, Miller, Blum, et al., 1994; see their table 16, Site 902; table 13, Site 903; table 12, Site 904; and table 11, Site 906). Most of the Oligocene and Miocene reflectors can be traced from the shelf, where reflector terminations indicate that they are seismic sequence boundaries (Greenlee et al., 1992). In addition, most of these reflectors correspond to lithologic changes, downhole log changes (Mountain, Miller, Blum, et al., 1994), impedance contrasts measured in cores (Mountain, Miller, Blum, et al., 1994; Lorenzo, this volume), and/or stratigraphic gaps detected in the slope boreholes (Miller et al., this volume), and are thus recognized as unconformities (sequence boundaries) on the slope. A few reflectors that do not correlate with obvious unconformities appear to correspond to "correlative conformities" (i.e., indiscernible hiatuses; e.g., Reflector $\mathrm{m} 6$ at Site 904) or the tops of sands that overlie unconformities (e.g., Reflector $\mathrm{ml}$ at Site 903).

We used the depths for the reflectors in the boreholes given by Mountain, Miller, Blum, et al. (1994) except for minor changes ${ }^{4}$ made by G.S. Mountain (pers. comm., 1995) and our own adjustments to Reflectors $\mathrm{m} 3$ to $\mathrm{m} 5$ at Sites 903 and 904 . Our detailed sampling for benthic foraminiferal changes across the $\mathrm{m} 3-\mathrm{m} 5$ sequence boundaries required the reevaluation of the precise reflector levels. We evaluated their correlations based on additional core impedance contrast data (Lorenzo and Hesselbo, this volume), reexamination of the lithologic descriptions, $\mathrm{Sr}$ isotopic data (Miller et al., this volume), and our benthic foraminiferal changes. The following changes are within the uncertainties of seismic-borehole correlations:

1. Reflector $\mathrm{m} 3 / 4$ (combined) at Site 904 could be placed at $\sim 244$ mbsf at the base of a sandy silt that is bracketed by $\mathrm{Sr}$ isotope ages of 13.0 ( $238.4 \mathrm{mbsf})$ and $16.0 \mathrm{Ma}$ ( $245 \mathrm{mbsf})$; this differs from the shipboard placement of $235 \mathrm{mbsf}$.

2. Reflector $\mathrm{m} 5$ at Site 904 is bracketed by $\mathrm{Sr}$ isotopic age estimates of 16.9 (257.39 mbsf) and $18.2 \mathrm{Ma}(264.20 \mathrm{mbsf})$; we tentatively place it near the lower analysis from near the base of a sandy silt; this reflector was tentatively identified by shipboard studies at 272 mbsf or above.

3. Reflector $\mathrm{m} 4$ at Site 903 could be placed near $850 \mathrm{mbsf}$ (as it was on the ship), associated with a possible short hiatus indicated by $\mathrm{Sr}$ isotope ages of 13.5 (836.41 mbsf depth at Hole 903D; 828.41 mbsf adjusted to Hole $903 \mathrm{C}$ depth) and $15.7 \mathrm{Ma}(852.49 \mathrm{mbsf}$ at Hole 903D; 846.49 mbsf adjusted to Hole 903C). However, note that $\mathrm{Sr}$ isotopes lack the resolution to define a hiatus this brief in this interval and that there is evidence that the reflector could be deeper. We prefer to place it at the base of a minor lithologic color change at 862 mbsf (Hole 903D depth; 854 mbsf at Hole 903C), near the level of an

${ }^{4}$ These changes include: Site 904: m1, $180.3 \mathrm{mbsf}$; m2, 220 mbsf; m6, $310 \mathrm{mbsf}$; Site 903: m3, 796 mbsf; Site 902: m6, 612 mbsf. 
Table 2. Age model parameters $(\mathrm{LO}=$ lowest occurrence, $\mathrm{HO}=$ highest occurrence, $\mathrm{Sr}=$ strontium isotope age).

\begin{tabular}{|c|c|c|}
\hline $\begin{array}{l}\text { Depth } \\
\text { (mbsf) }\end{array}$ & $\begin{array}{c}\text { Age } \\
\text { (m.y.) }\end{array}$ & Datum \\
\hline $\begin{array}{r}\text { Site 902: } \\
595.52 \\
609.81 \\
616.47 \\
677.04 \\
680.94 \\
728.54\end{array}$ & $\begin{array}{l}22.04 \\
23.16 \\
26.60 \\
30.20 \\
37.00 \\
38.00\end{array}$ & $\begin{array}{l}\mathrm{Sr} \\
\mathrm{Sr} \\
\mathrm{Sr} \\
\mathrm{Sr} \\
\text { Arbitrary level within late NP19-20 } \\
\text { Within NP19/20 }\end{array}$ \\
\hline $\begin{array}{r}\text { Site } 903: \\
558.82 \\
756.50 \\
788.00 \\
903.72 \\
910.50 \\
1000.00 \\
1003.00 \\
1064.10 \\
1064.13 \\
1112.40 \\
1113.00 \\
1121.00 \\
1136.00\end{array}$ & $\begin{array}{l}10.40 \\
12.83 \\
13.01 \\
16.30 \\
18.20 \\
22.17 \\
24.00 \\
32.00 \\
37.00 \\
38.50 \\
40.00 \\
40.60 \\
42.00\end{array}$ & $\begin{array}{l}\text { HO P. mayeri? } \\
\text { Top C5AA } \\
\text { Base C5AA } \\
\text { Sr } \\
\text { Sr } \\
\text { Within NN2 } \\
\text { Sr } \\
\text { Extrapolated sedimentation rate from below } \\
\text { Upper NP19-20 } \\
\text { LO I. recurvus } \\
\text { Base NP18 } \\
\text { HO Acarinina spp. } \\
\text { Top NP16 }\end{array}$ \\
\hline $\begin{array}{r}\text { Site } 904: \\
176.50 \\
182.00 \\
184.00 \\
198.50 \\
226.50 \\
243.50 \\
245.00 \\
257.42 \\
264.22 \\
305.90 \\
334.30 \\
341.21 \\
417.92 \\
417.93 \\
428.00 \\
463.00 \\
480.73 \\
548.47 \\
565.28\end{array}$ & $\begin{array}{r}8.00 \\
11.47 \\
11.55 \\
12.12 \\
12.83 \\
13.30 \\
16.00 \\
16.90 \\
18.10 \\
23.70 \\
28.20 \\
37.00 \\
38.50 \\
44.30 \\
44.70 \\
46.00 \\
47.00 \\
48.80 \\
52.00\end{array}$ & $\begin{array}{l}\text { Arbitrary level in } \mathrm{C} 4 \mathrm{n} \\
\text { Extrapolated sedimentation rate from below } \\
\text { Top C5An } \\
\text { Top C5Ar } \\
\text { Top CSAA } \\
\text { Level of unconformity } \\
\text { Sr } \\
\mathrm{Sr} \\
\mathrm{Sr} \\
\text { LO G. kugleri } \\
\mathrm{Sr} \\
\text { Arbitrary level within late NP19-20 } \\
\text { Microtektite layer } \\
\text { Interpolated from below } \\
\text { LO T. pomeroli } \\
\text { LO M. lehneri } \\
\text { HO C. gigas } \\
\text { LO C. gigas } \\
\text { NP14a; HO S. sublodensis }\end{array}$ \\
\hline $\begin{array}{c}\text { Site 906: } \\
279.20 \\
478.199 \\
478.20 \\
555.50 \\
563.80 \\
599.20\end{array}$ & $\begin{array}{l}12.50 \\
13.50 \\
27.00 \\
30.40 \\
37.00 \\
38.00\end{array}$ & $\begin{array}{l}\text { Correlated with } \mathrm{m} 2 \\
\text { Base of Miocene } \\
\text { Top of Oligocene } \\
\text { Base of Oligocene } \\
\text { Top of Eocene } \\
\text { Arbitrary level within early NP19-20 }\end{array}$ \\
\hline $\begin{array}{r}\text { Site } 612: \\
136.20 \\
181.39 \\
183.00 \\
331.70 \\
337.50 \\
530.60\end{array}$ & $\begin{array}{l}36.60 \\
38.50 \\
43.00 \\
51.00 \\
52.00 \\
55.20\end{array}$ & $\begin{array}{l}\text { HO Hantkenina spp. } \\
\text { Microtektite layer } \\
\text { Within range of } A \text {. bullbrooki } \\
\text { Arbitrary level within Zone P10 } \\
\text { HO } M \text {. caucasica } \\
\text { LO } M \text {. aragonenesis }\end{array}$ \\
\hline $\begin{array}{r}\text { Site 613: } \\
269.00 \\
336.00 \\
430.00 \\
440.00 \\
578.00\end{array}$ & $\begin{array}{l}43.00 \\
46.00 \\
50.20 \\
52.00 \\
55.20\end{array}$ & $\begin{array}{l}\text { Within range of } A . \text { bullbrooki } \\
\text { HO } M \text {. aragonenesis } \\
\text { LO } T \text {. rohri } \\
\text { HO } M \text {. caucasica } \\
\text { LO } M \text {. caucasica }\end{array}$ \\
\hline $\begin{array}{r}\text { Site } 390: \\
8.70 \\
31.05 \\
45.00 \\
70.84\end{array}$ & $\begin{array}{l}44.00 \\
45.90 \\
52.00 \\
55.20\end{array}$ & $\begin{array}{l}\text { Arbitrary level in } \mathrm{P} 12 \\
\text { HO } M \text {. aragonenesis } \\
\text { LO Hantkenina } \text { spp. } \\
\text { LO } M \text {. aragonenesis }\end{array}$ \\
\hline
\end{tabular}

increase in core impedance contrast at $860 \mathrm{mbsf}$ (Hole 903D depth; $852 \mathrm{mbsf}$ at Hole $903 \mathrm{C}$ depth). However, we indicate an interval from 852 to 862 mbsf on the Site 903 figures to reflect the uncertainty in the placement of Reflector $\mathrm{m} 3$.

4. Reflector $\mathrm{m} 5$ at Site 903 is bracketed by $\mathrm{Sr}$ isotopic age estimates of 16.2 Ma (903.71 mbsf at Hole 903D; $895.71 \mathrm{~m}$ at Hole 903C) and 18.2 Ma (910.20 mbsf at Hole 903D; 902.20 mbsf at Hole 903C), indicating correlation similar to the shipboard placement at $900 \mathrm{mbsf}$ if depths are corrected to an 8-m deeper offset at Hole
903D, or 908 mbsf using Hole 903D depths (samples are plotted using Hole 903D depths in this study). Lithologic studies show the base of a glauconite unit at $908.4 \mathrm{~m}$ at Hole 903D (900.4 mbsf at Hole 903C), and this is where we place the reflector.

We used factor analysis, species percentages, and number of benthic foraminifers per gram to identify patterns associated with the $\mathrm{m} 5$ sequence at Sites 903 and 904 . Factor analysis did not provide results that were stratigraphically meaningful, but helped to delineate the dominant taxa within the sections. We plotted species percentages based on the factor analysis results, and identified several species abundance changes that appear to be related to sequence stratigraphy.

\section{RESULTS AND DISCUSSION Leg 150 Biofacies}

\section{Site 904}

At Site 904 (1123 m present water depth; 1020-1120 m paleodepth), five factors explain $58 \%$ of the faunal variation ( 45 samples and 141 taxa). The lower to middle Eocene biofacies (Factor 2) is characterized by Lenticulina spp. and Alabamina wilcoxensis, with secondary faunal components (Figs. 2, 3). No biofacies change is associated with the disconformable lower/middle Eocene boundary or with the transition from porcellanitic chalks to chalks at $\sim 525$ mbsf (= Reflector e2, Fig. 3; equivalent to Horizon $\mathrm{A}^{\mathrm{c}}$ of Tucholke and Mountain, 1979). The Lenticulina spp.-Alabamina wilcoxensis biofacies was replaced by an upper Eocene biofacies characterized by Pullenia bulloides, Osangularia spp., polymorphinids, and Gyroidinoides spp. (Factor 3) and Bulimina alazanensis (Factor 1) (Figs. 2, 3). Factor 1 is dominated by B. alazanensis and has peaks in the upper Eocene and middle Miocene. A major faunal abundance change occurs across the disconformable Eocene/upper Oligocene contact from Factors 3 and 1 below to Factor 5 above; this is most likely the result of the nearly 10-m.y. hiatus at this contact (Mountain, Miller, Blum, et al., 1994).

The upper Oligocene to lower middle Miocene section at Site 904 contains an in situ bathyal benthic foraminiferal biofacies represented by Factor 4 (characterized by Stilostomella spp., Uvigerina hispida, Cibicidoides pachyderma, Buliminella gracilis, Bulimina macilenta, Martinottiella communis, and Melonis barleeanum) and Factor 5 (characterized by Uvigerina proboscidea, Stilostomella modesta, Plectofrondicularia spp., M. barleeanum, Lenticulina spp., and Stilostomella spp.) (Figs. 2,3). Within this section, the Factor 5 biofacies characterizes the intervals immediately above Reflectors ol, m6, and $\mathrm{m} 5$, whereas the Factor 4 biofacies characterizes the upper parts of the sequences. This is consistent with our findings in the high-resolution intrasequence study (see below), where $U$. proboscidea percentages are high above reflectors (i.e., in the lower part of the overlying sequence) and Stilostomella spp. percentages are high below reflectors (i.e., in the upper part of the underlying sequence). A similar pattern is associated with Reflectors $\mathrm{m} 3$ and $\mathrm{m} 2$, with Factor 1 biofacies (B. alazanensis) occurring immediately above the reflectors and Factor 4 biofacies (dominated by Stilostomella spp.) in the upper part of the sequence (Figs. 2, 3). Part of the middle Miocene section contains transported components (dominated by Buliminella gracilis) mixed with predominantly in situ taxa (see below). Transported taxa dominate the upper middle to upper Miocene section (Figs. 2, 3).

\section{Site 906}

At Site 906 (913 m present water depth; 870-930 m paleodepth), five factors explain $75 \%$ of the faunal variation (31 samples and 109 taxa). Middle Eocene strata were not penetrated at this site. The upper Eocene section is characterized by an Osangularia spp., P. bulloides, 
Table 3. Age/paleobathymetric distributions of taxa in this study ( $R S=$ restricted to; $C=$ most common in).

\begin{tabular}{|c|c|c|}
\hline Taxon & Age & Paleodepth \\
\hline Alabamina wilcoxensis & $C$ early Eocene to earliest Miocene & $C$ bathyal \\
\hline Anom. aragonensis/capitatus & $R S$ Eocene; $C$ early to middle Eocene & $C$ lower bathyal \\
\hline $\begin{array}{l}\text { A. pseudogrosserugosus } \\
\text { A. spissiformis }\end{array}$ & $\begin{array}{l}C \text { late Oligocene to early Miocene } \\
C \text { early to middle Eocene }\end{array}$ & \\
\hline $\begin{array}{l}\text { A. spissiformis } \\
\text { Aragonia aragonensis }\end{array}$ & $C$ middle Eocene & $C$ lower bathyal \\
\hline Arenobulimina truncata & RS Eocene & \\
\hline Bolivina advena & $C$ late Oligocene to early Miocene & $R S$ middle to upper bathyal \\
\hline B. furcata & $R S$ middle early Miocene & \\
\hline B. tectiformis & $R S$ late Eocene & \\
\hline Bulimina alazanensis & $\begin{array}{l}C \text { late Eocene and middle Miocene } \\
R S \text { Eocene }\end{array}$ & \\
\hline B. impendens & RS Eocene & $C$ bathyal \\
\hline B. macilenta & & \\
\hline $\begin{array}{l}\text { B. semicostata } \\
\text { B. subtruncana }\end{array}$ & $\begin{array}{l}R S \text { early to middle middle Eocene } \\
R S \text { late Eocene }\end{array}$ & $\begin{array}{l}C \text { abyssal } \\
R S \text { bathyal }\end{array}$ \\
\hline B. trinitatensis & $R S$ early to middle Eocene & \\
\hline B. bradbury/tuxpamensis & $R S$ Eocene; $C$ middle to late Eocene & $C$ bathyal \\
\hline Buliminella gracilis & $C$ late middle Miocene & \\
\hline B. grata & $R S$ Eocene; $C$ early Eocene & $C$ abyssal \\
\hline Cassidulina spp. & $C$ late Eocene and middle Miocene & \\
\hline Cassidulinoides spp. & $R S$ late Oligocene to middle Miocene & \\
\hline Cibicidoides bradyi & $C$ late Eocene & $R S$ bathyal \\
\hline C. cookei & $R S$ Eocene & $R S$ bathyal \\
\hline C. crebbsi & $R S$ middle early to middle Miocene & \\
\hline C. dickersoni & $C$ middle to late Eocene & \\
\hline C. eocaenus & $\begin{array}{l}R S \text { Eocene } \\
R S \text { Eocene }\end{array}$ & \\
\hline C. havanensis & $\begin{array}{l}\text { RS Eocene } \\
\text { Clate Eocene }\end{array}$ & $R S$ bathyal \\
\hline $\begin{array}{l}\text { C. laurisae } \\
\text { C. micrus }\end{array}$ & $\begin{array}{l}C \text { late Eocene } \\
R S \text { Eocene }\end{array}$ & \\
\hline C. pachyderma & $R S$ latest Oligocene to Miocene & \\
\hline C. praemundulus & & $C$ lower bathyal \\
\hline Cibicidoides sp. A & $C$ late Eocene to Oligocene & \\
\hline Dorothia sp. & RS Eocene & \\
\hline Eggerella spp. & & $C$ bathyal \\
\hline Fursenkoina makiyama & & \\
\hline Globobulimina notovata & $\begin{array}{l}C \text { late Eocene to late Oligocene } \\
C \text { late Oligocene to middle Miocene }\end{array}$ & $R S$ lower bathyal \\
\hline $\begin{array}{l}\text { Globobulmma spp. } \\
\text { Globocassidulina subglobosa }\end{array}$ & $\begin{array}{l}\text { Clate Oligocene to middle Miocene } \\
C \text { late Eocene to middle Miocene }\end{array}$ & \\
\hline Gyroidinoides sp. 1 & RS Eocene to Oligocene & \\
\hline Gyroidinoides spp. & $C$ late middle Eocene to Miocene & $C$ bathyal \\
\hline Hanzawaia ammophila & $C$ early to middle Eocene & $C$ lower bathyal \\
\hline Hoeglundina elegans & RS Oligocene to Miocene & \\
\hline Karreriella chapapotensis & $C$ Eocene & \\
\hline K. subglabra & $\begin{array}{l}C \text { Eocene } \\
C \text { Eocene }\end{array}$ & \\
\hline $\begin{array}{l}\text { Karreriella spp. } \\
\text { Lenticulina peregrina }\end{array}$ & $\begin{array}{l}C \text { Eocene } \\
R S \text { late Oligocene to early Miocene }\end{array}$ & $R S$ middle bathyal \\
\hline Lenticulina spp. & & $C$ bathyal \\
\hline Loxostomum cf. applinae & RS late Oligocene to middle Miocene & \\
\hline Marginulina hirsuta & RS latest middle Eocene to middle Miocene & \\
\hline Martinottiella communis & $R S$ Miocene; $C$ middle Miocene & \\
\hline Melonis barleeanum & $C$ late Oligocene to middle Miocene & \\
\hline M. pompilioides & $C$ late Oligocene to middle Miocene & \\
\hline Nonion havanense & $\begin{array}{l}\text { RS Eocene } \\
C \text { late early to middle Miocene }\end{array}$ & \\
\hline $\begin{array}{l}\text { Nonionella pizarrensis } \\
\text { Nonionellina spp. }\end{array}$ & $\begin{array}{l}C \text { late early to middle Miocene } \\
C \text { middle to late Eocene }\end{array}$ & $C$ bathyal \\
\hline Nuttallides truempyi & RS early to middle middle Eocene & $C$ abyssal \\
\hline Osangularia spp. & $C$ Eocene & $C$ bathyal \\
\hline Pararotalia spp. & $R S$ middle Miocene & \\
\hline Planulina aff. ambigua & $C$ middle Miocene & $R S$ upper to middle bathyal \\
\hline Planulina costata & $C$ late Eocene & $R S$ bathyal \\
\hline Plectina elongata & $R S$ Eocene; $C$ middle Eocene & $C$ lower bathyal \\
\hline Plectofrondicularia spp. & $C$ late Oligocene & $C$ upper to middle bathyal \\
\hline Plectofrondicularia spp. & $C$ Miocene & $C$ lower bathyal \\
\hline Pleurostomella spp. & $C$ Eocene & $C$ bathyal \\
\hline Pleurostomellids & RS Eocene & \\
\hline Polymorphinids & $C$ late Eocene to Miocene & \\
\hline Praeglobobulimina spinescens & $C$ late Oligocene & $C$ middle to lower bathyal \\
\hline Pullenia bulloides & $C$ late Eocene & \\
\hline P. eocenica & $C$ middle Eocene & \\
\hline P. quinqueloba & $C$ Eocene to Oligocene & $C$ bathyal \\
\hline Quadratobuliminella pyramidalis & $R S$ early to middle Eocene & $R S$ abyssal \\
\hline Spirosigmoilina tenuis & $R S$ late Eocene to Miocene & \\
\hline Siphonina tenuicarinata & $C$ late Oligocene to early middle Miocene & \\
\hline Siphonina sp. & $R S$ early to earliest middle Eocene & $R S$ lower bathyal \\
\hline Sphaeroidina bulloides & $C$ late Oligocene & \\
\hline Spiroloculina sp. & $R S$ Oligocene to Miocene; $C$ early Miocene & $R S$ middle to lower bathyal \\
\hline ctabilis & $R S$ EO & \\
\hline Spirosigmoilina tenuis & RS late Eocene to middle Miocene & $C$ middle to lower bathyal \\
\hline Stilostomella aculeata & $C$ Eocene & \\
\hline Stilostomella sp. C & RS late Oligocene to middle Miocene & \\
\hline S. modesta & RS late Oligocene to middle Miocene & $R S$ lower bathyal \\
\hline S. paucistriata & $R S$ late Eocene & \\
\hline Total Stilostomella spp. & $C$ late Eocene to middle Miocene & \\
\hline Trifarina danvillensis & $C$ late Eocene & \\
\hline Turrilina robertsi & RS Eocene & $C$ lower bathyal \\
\hline Uvigerina adelinensis & RS middle Miocene & $R S$ upper bathyal \\
\hline U. auberiana & $C$ late Eocene & \\
\hline U. aubertae & $R S$ early to middle Miocene & lower bathyal \\
\hline
\end{tabular}


Table 3 (continued).

\begin{tabular}{lll}
\hline \multicolumn{1}{c}{ Taxon } & \multicolumn{1}{c}{ Age } & \multicolumn{1}{c}{ Paleodepth } \\
\hline U. chirana & C late Oligocene & \\
U. havanensis & $R S$ middle to late Eocene & $R S$ bathyal \\
U. hispida & $C$ middle Miocene & \\
U. mexicana & $C$ latest Eocene to the late Oligocene & $C$ middle bathyal \\
U. pigmea & $R S$ middle Miocene & \\
U. proboscidea & $C$ late Oligocene to the early Miocene & \\
U. semivestita & $R S$ late Eocene & $R S$ lower bathyal \\
U. spinulosa & $R S$ late Eocene to earliest Miocene & $R S$ middle bathyal \\
Vulvulina spp. & $C$ early to middle Eocene & \\
\hline
\end{tabular}

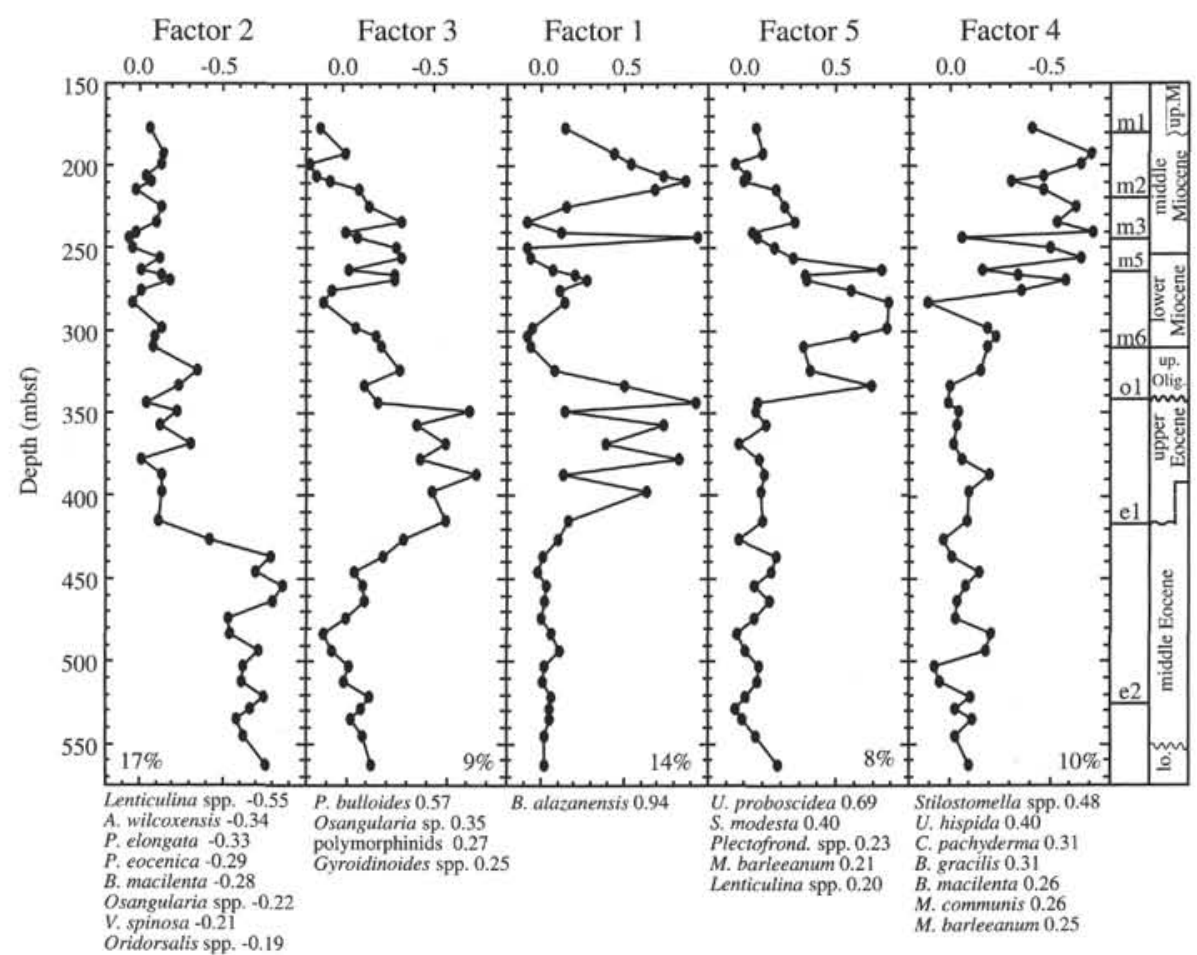

Figure 2. Site 904 Q-mode varimax factors. Percentage of the faunal variation explained by each factor and the species with the highest scores on each factor are shown. See Appendix for full taxonomic designations. Seismic stratigraphic correlations are after Mountain, Miller, Blum, et al. (1994) except where noted in the text.

B. alazanensis, and Oridorsalis spp. dominated fauna (Factor 3; Figs. 4,5 ), similar to the coeval biofacies at nearby Site 902 and deeper Site 904. A shift in biofacies occurs across the disconformable Eocene/upper Oligocene contact from Factor 3 to Factors 4 and 1. Most of the upper Oligocene at Site 906 is dominated by the Factor 1 biofacies (Lenticulina spp., Cibicidoides aff. praemundulus, and A. wilcoxensis), with some samples showing high loadings on Factors 4 and 5 (Stilostomella sp. C, polymorphinids, Plectofrondicularia spp., M. barleeanum, Melonis pompilioides, Gyroidinoides spp., and Globocassidulina subglobosa) (Figs. 4, 5). The upper Oligocene biofacies at Site 906 is comparable to that at nearby Site 902 , which has a similar modern and backstripped water depth. The middle Miocene section examined at Site 906 consists of canyon fill deposited on Reflector $\mathrm{m} 3$; the biofacies of this canyon fill (Factor 2) are characterized by in situ taxa (Uvigerina hispida, B. alazanensis, Cibicidoides pachyderma, Cibicidoides crebbsi) mixed in with transported neritic foraminifers (Buliminella gracilis) (Figs. 4, 5). Of the three canyonfill lithostratigraphic units, we only examined samples from the lower mud-clast conglomerate Unit VC (i.e., below reflector canyon 2, Fig. 5; Mountain, Miller, Blum, et al., 1994).

\section{Site 902}

At Site 902 (811 m present water depth; 790-830 m paleodepth), five factors explain $77 \%$ of the faunal variation (41 samples and 108 taxa). Middle Eocene strata were not penetrated at this site. The upper Eocene section is characterized by a $P$. bulloides, $B$. alazanensis, Osangularia spp., Gyroidinoides spp., and Oridorsalis spp. biofacies (Factors 2 and 4; Figs. 6, 7), similar to coeval biofacies at Sites 904 and 906. Bulimina alazanensis is characteristic of the upper Eocene section at Site 902 (Factor 2), as it is at Sites 904 and 906. Factors 1, 3 , and 5 (Lenticulina spp. and polymorphinids, Factor 1; Uvigerina mexicana, M. pompilioides, A. ignota, and Stilostomella spp., Factor 3; and $A$. wilcoxensis and $M$. barleeanum, Factor 5) characterize the upper Oligocene section at Site 902, while Factors 1 and 5 characterize the lower Miocene section (Figs. 6, 7). There is an unusually high degree of fluctuation among Factors 1, 3, and 5 at Site 902, although these biofacies are generally similar to those found at the other Leg 150 sites at coeval levels. These faunal variations may reflect local influences, high frequency climatic variations, or be an artifact of factor analysis. 


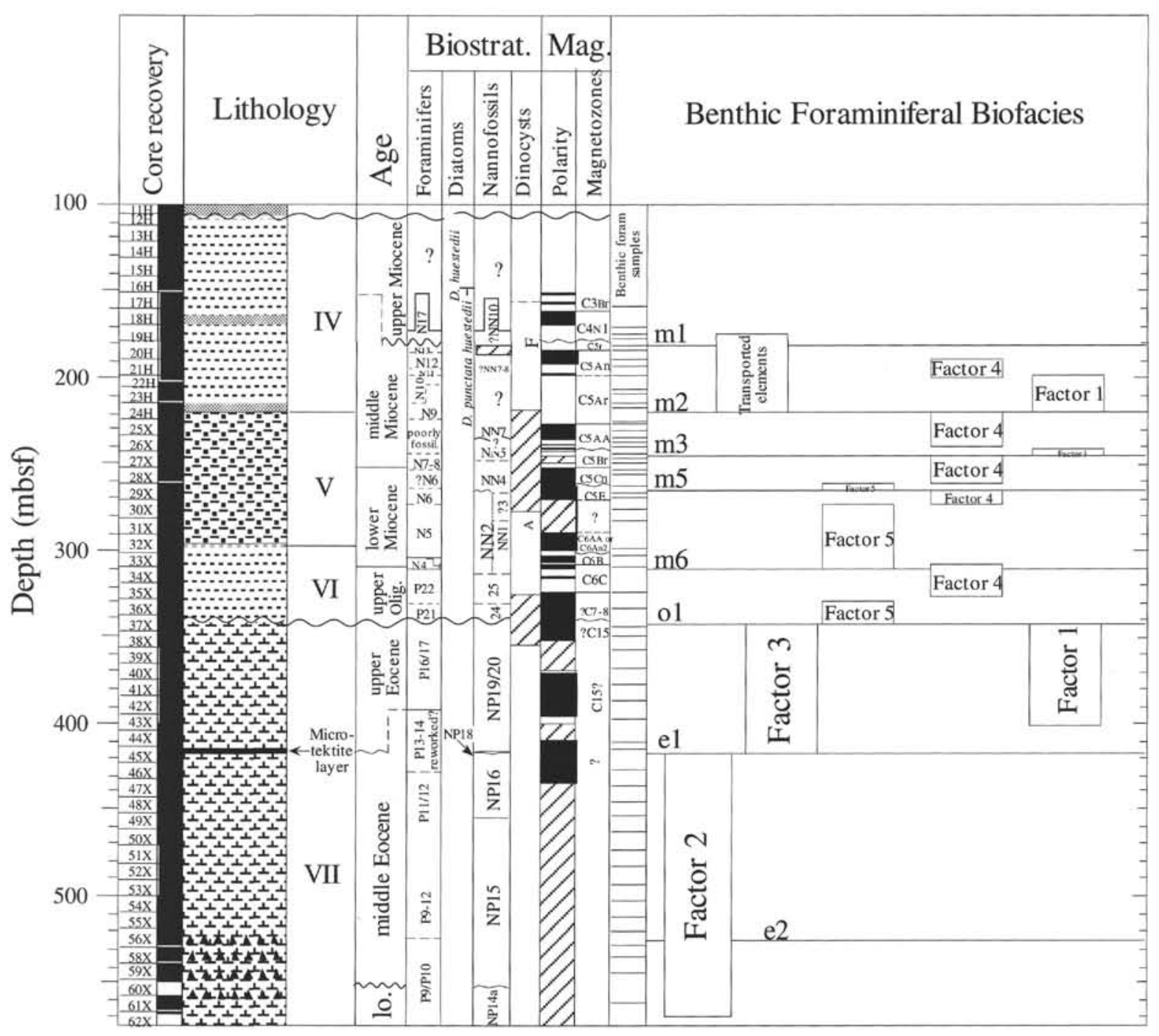

Figure 3. Site 904 biofacies represented by Q-mode varimax factors. Seismic stratigraphic correlations are after Mountain, Miller, Blum, et al. (1994) except where noted in the text. Biostratigraphy includes planktonic foraminifers (Snyder et al., this volume), nannofossils, diatoms, and dinocysts (Mountain, Miller, Blum, et al., 1994). Lithostratigraphy is after Mountain, Miller, Blum, et al. (1994). Magnetostratigraphy is after Van Fossen and Urbat (this volume).

\section{Site 903}

At Site 903 (444 m present water depth; 470-500 m paleodepth), five factors explain $65 \%$ of the faunal variation ( 34 samples and 132 taxa). The middle to upper Eocene section is characterized by faunas (P. bulloides, B. alazanensis, Osangularia spp., Cibicidoides aff. praemundulus, and Lenticulina spp.; Factors 1 and 3; Figs. 8, 9) similar to those found at the deeper Sites 902, 904, and 906. As at all other Leg 150 sites, a faunal change is associated with the disconformable Eocene/Oligocene boundary as the Factor 1 biofacies (Lenticulina spp., polymorphinids, U. proboscidea, A. wilcoxensis, $M$. barleeanum, and Gyroidinoides spp.) becomes dominant in the upper Oligocene section.

In the lower to lower middle Miocene section at Site 903, the dominant biofacies fluctuates among Factor 1, Factor 4 (Cibicidoides crebbsi, Globocassidulina subglobosa, and Stilostomella spp.), and Factor 5 (M. pompilioides, Uvigerina aubertae, Martinottiella communis, U. hispida, Cibicidoides aff. mundulus, Stilostomella sp. C, $U$. proboscidea, and $U$. adelinensis). The Factor 5 biofacies (dominated by $M$. pompilioides) shows peaks associated with Reflectors $\mathrm{m} 6$ and $\mathrm{m} 4$; below, we show that the taxon $M$. pompilioides has abundance peaks that span Reflectors $\mathrm{m} 4$ and $\mathrm{m} 5$ at this site. An interval in the lower Miocene yielded rare benthic foraminifers. The upper Oligocene to lower middle Miocene biofacies at Site 903 are similar to coeval Site 902 biofacies. Whereas there are similarities to coeval Site 904 faunas, there are minor distinctions in the benthic foraminiferal composition that reflect shallower water depths at Site 903. For example, Cibicidoides crebbsi (dominant Factor 4 species) and $\mathrm{Mel}$ onis pompilioides (dominant Factor 5 species) are more common at Site 903 than at Site 904; these taxa tend to be most abundant shallower than $\sim 1000 \mathrm{~m}$ (van Morkhoven et al., 1986; Katz and Miller, 1993). As at the other Leg 150 sites, B. alazanensis shows peak abundances in the upper Eocene and in the middle Miocene at Site 903. Factor 2 (Buliminella gracilis, Uvigerina hispida, Bulimina alazanensis, Melonis barleeanum, and Uvigerina pigmea) characterizes part of the middle Miocene section at Site 903.

Downslope transport becomes significant in the middle Miocene section at Site 903 near Reflector m3. Buliminella gracilis and Uvigerina elongata are most common at inner to middle neritic depths $(<100 \mathrm{~m})$ on the New Jersey Oligocene to Miocene coastal plain (Olsson et al., 1980), deltaic environments on the New Jersey shelf (Poag, 1978), and on the Maryland Miocene coastal plain (Gibson, 


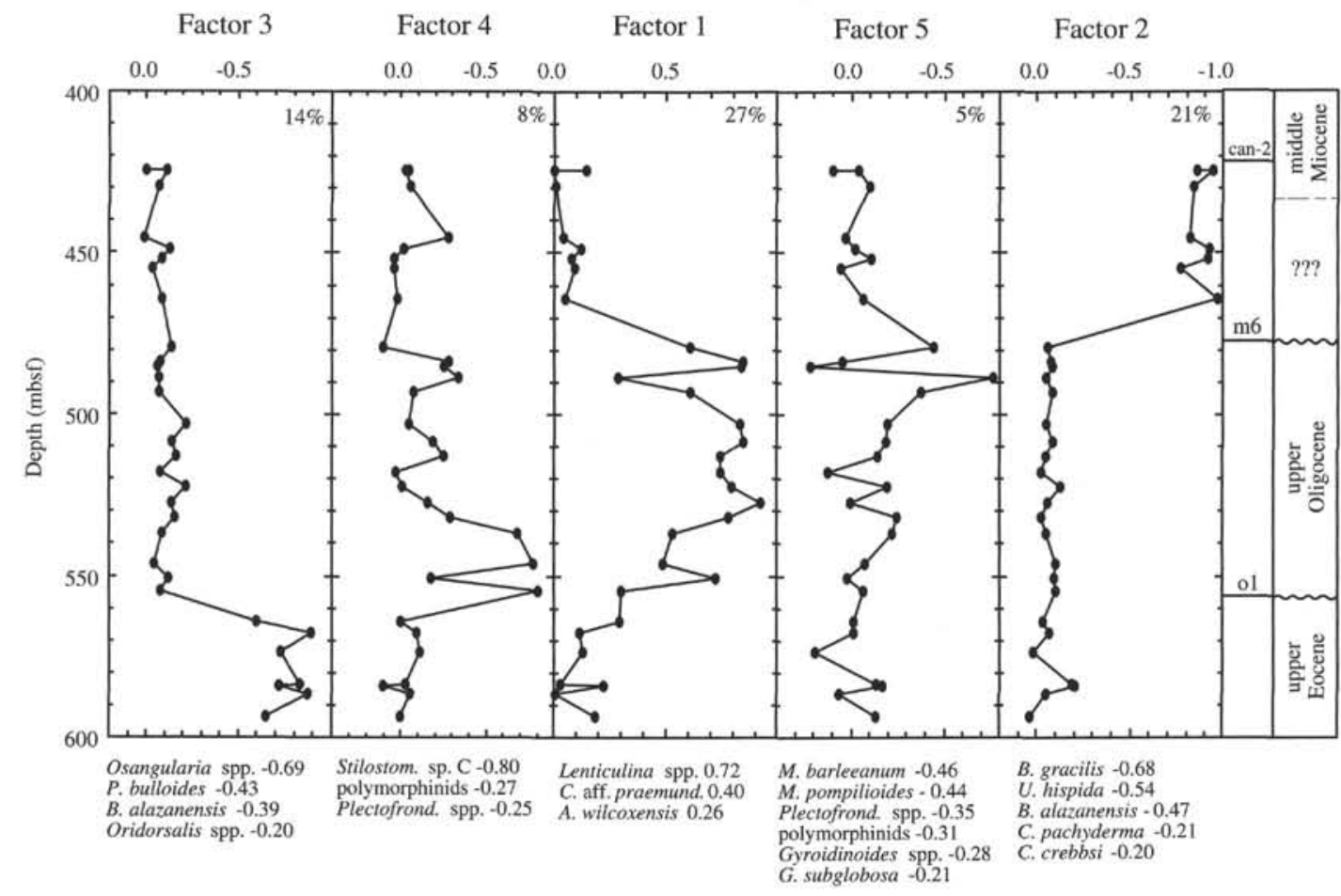

Figure 4. Site 906 Q-mode varimax factors. Percentage of the faunal variation explained by each factor and the species with the highest scores on each factor are shown. See Appendix for full taxonomic designations. Seismic stratigraphic correlations are after Mountain, Miller, Blum, et al. (1994) except where noted in the text.

1972); we use these taxa as indicators of downslope transport. Factor 2 represents mixed in situ and transported material $(B$. gracilis is $<27 \%$ in Factor 2). Buliminella gracilis comprises $80 \%-100 \%$ of the biofacies above Reflector $\mathrm{m} 2$ (700 mbsf; Mountain, this volume), and Uvigerina elongata comprises nearly $100 \%$ of the faunas above Reflector m1 (604.50 mbsf; Mountain, this volume) (Fig. 9), indicating that allochthonous facies dominate much of the middle Miocene section at Site 903.

\section{Biofacies Age vs. Paleodepth Distribution on the New Jersey Transect}

The New Jersey Transect provides a record from the bathyal to abyssal zones for most of the Eocene. As a result of poor core recovery at abyssal sites drilled prior to Leg 150 (Poag, Watts, et al., 1987; van Hinte, Wise, et al., 1987), Oligocene to Miocene records are limited to the bathyal zone in this region. The age vs. paleodepth coverage is comprehensive for the Eocene through middle Miocene bathyal samples and for the lower to middle Eocene abyssal samples (Figs. 10,11 ). We present bubble plots both for factors (Figs. 10,11) and for species percentages (Fig. 12A-L).

The age vs. paleobathymetric distributional data presented here (Table 3; Fig. 12A-L) are consistent with previous studies for the Eocene Atlantic (e.g., Tjalsma and Lohmann, 1983), the Oligocene Atlantic (M.E. Katz, K.G. Miller, and R.C. Tjalsma, unpubl. data, 1995), and the Neogene of the Gulf of Mexico (Katz and Miller, 1993). For instance, Nuttallides truempyi abundances decreased dramatically in the middle Eocene; on the New Jersey Margin, this species disappeared by the end of the middle Eocene (Fig. 12G), whereas it was present elsewhere in very low numbers into the late Eocene (e.g., Katz and Miller, 1991; Thomas, 1990; Tjalsma and Lohmann, 1983). Other common cosmopolitan Eocene species that are found on the New Jersey Margin include Aragonia aragonensis, Bulimina impendens, B. semicostata, B. trinitatensis, B. tuxpamensis, Cibici- doides micrus, Hanzawaia ammophila, Nonion havanense, and Quadratobuliminella pyramidalis (additional common Eocene taxa are shown in Fig. 12A-L).

Other taxa also show depth and/or age distributions on the New Jersey Margin that are similar to other Atlantic locations. For instance, Osangularia spp. and Pleurostomella spp. were most abundant in the Eocene bathyal zone at the Leg 150 sites (Fig. 12A-L), whereas polymorphinids were most abundant in the late Eocene to the Miocene (Fig. 12I). Similarly, Tjalsma and Lohmann (1983) showed that Osangularia mexicana was most abundant in the Eocene bathyal zone in the circum-Atlantic region. Globocassidulina subglobosa (Fig. 12E), Gyroidinoides spp. (Fig. 12E), and Stilostomella spp. (Fig. 12K) abundances increased in the late Eocene bathyal zone and continued to be major faunal constituents through the middle $\mathrm{Mi}$ ocene. Tjalsma and Lohmann (1983) found that abundances of Globocassidulina subglobosa, Gyroidinoides spp., and Stilostomella spp. increased in the middle Eocene at many of their abyssal circum-Atlantic sites, which is consistent with the New Jersey Margin distributions.

Some taxa appear to have restricted age or paleodepth distributions on the New Jersey Margin compared to other locations. Bolivina tectiformis (Fig. 12B), Bulimina subtruncana (Fig. 12B), Stilostomella paucistriata (Fig. 12J), and Uvigerina semivestita (Fig. $12 \mathrm{~L}$ ) were restricted to the late Eocene at our slope sites, but have wider distributions at other Atlantic locations. For example, Bolivina tectiformis has been reported at abyssal paleodepths in Oligocene to Miocene sediments in the North Atlantic (Miller and Katz, 1987b) and at a bathyal paleodepth in Oligocene South Atlantic sediments (Tjalsma, 1983). Uvigerina semivestita has been reported at middle to upper lower bathyal depths in upper Eocene to Oligocene Atlantic sediments (Boersma, 1984).

Eocene benthic foraminifers on the New Jersey Transect represent cosmopolitan deep-water faunas. Early to middle Eocene bathyal biofacies (Sites 108, 612, 902, 903, 904, and 906) were character- 




Figure 5. Site 906 biofacies represented by Q-mode varimax factors. Seismic stratigraphic correlations are after Mountain, Miller, Blum, et al. (1994) except where noted in the text. Biostratigraphy includes planktonic foraminifers (Snyder et al., this volume), nannofossils, diatoms, and dinocysts (Mountain, Miller, Blum, et al., 1994). Lithostratigraphy is after Mountain, Miller, Blum, et al. (1994). Magnetostratigraphy is after Van Fossen and Urbat (this volume).

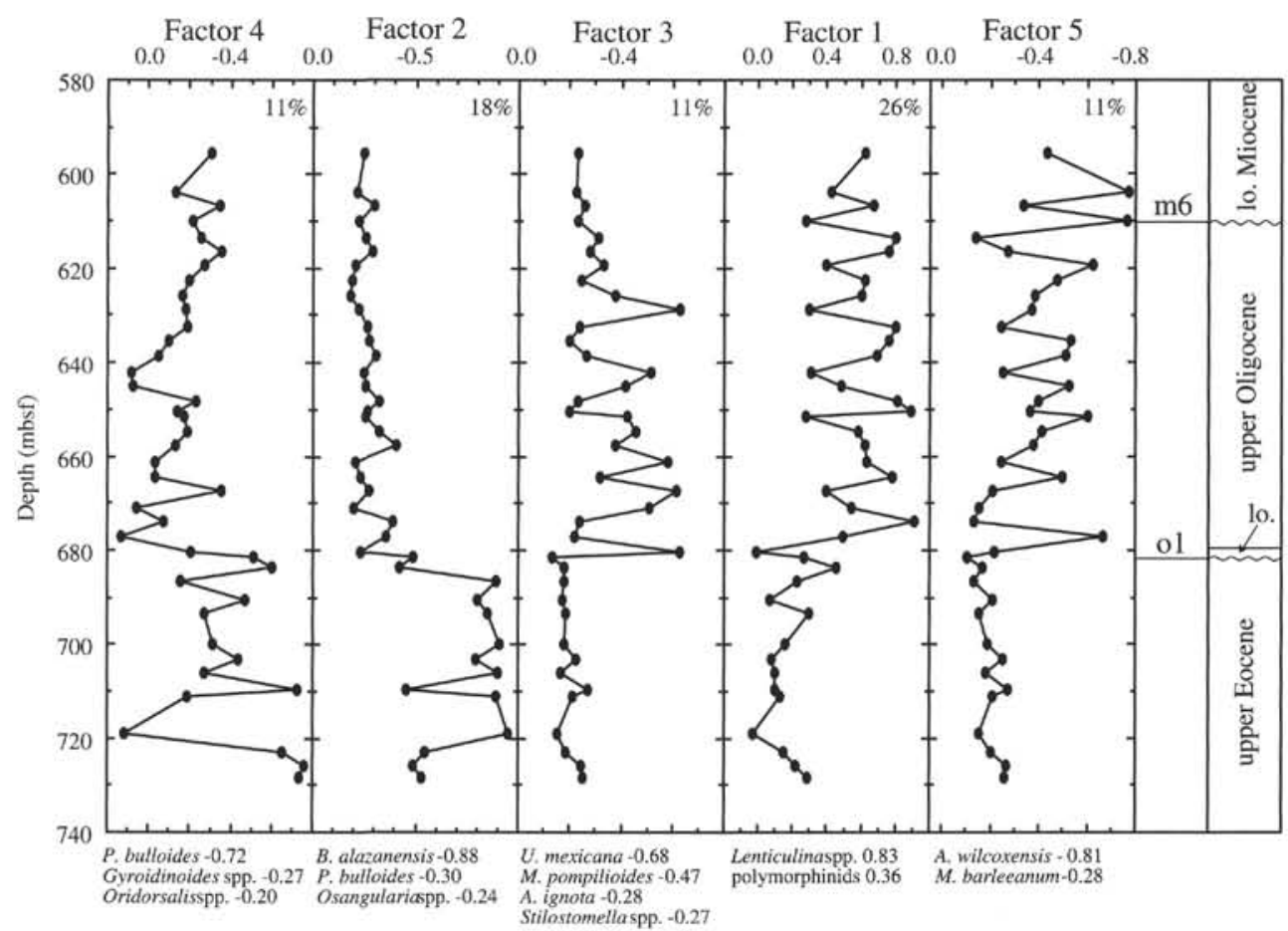

Figure 6. Site 902 Q-mode varimax factors. Percentage of the faunal variation explained by each factor and the species with the highest scores on each factor are shown. See Appendix for full taxonomic designations. Seismic stratigraphic correlations are after Mountain, Miller, Blum, et al. (1994) except where noted in the text. 




Figure 7. Site 902 biofacies represented by Q-mode varimax factors. Seismic stratigraphic correlations are after Mountain, Miller, Blum, et al. (1994) except where noted in the text. Biostratigraphy includes planktonic foraminifers (Snyder et al., this volume), nannofossils, diatoms, and dinocysts (Mountain, Miller, Blum, et al., 1994). Lithostratigraphy is after Mountain, Miller, Blum, et al. (1994). Magnetostratigraphy is after Van Fossen and Urbat (this volume).

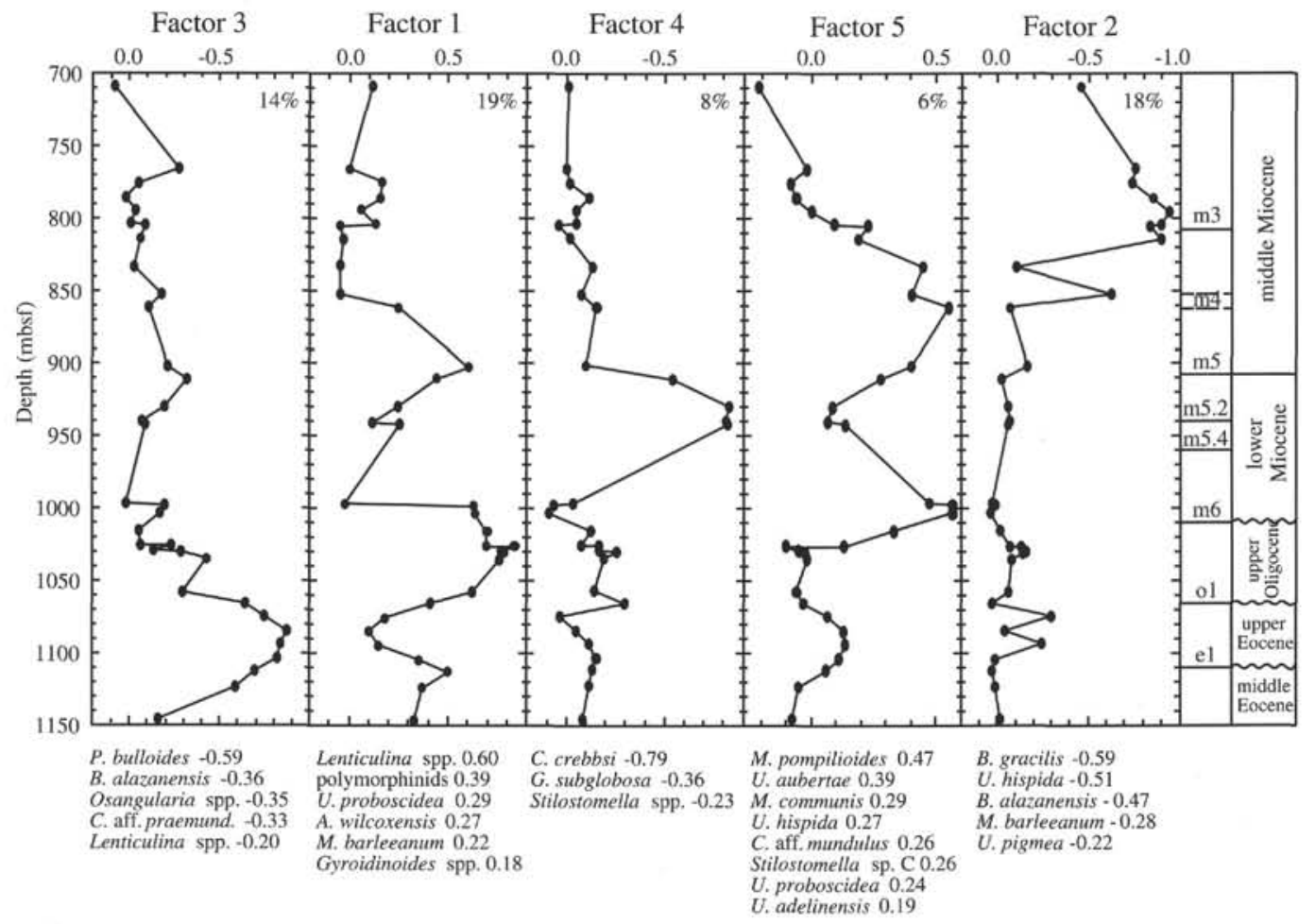

Figure 8. Site 903 Q-mode varimax factors. Percentage of the faunal variation explained by each factor and the species with the highest scores on each factor are shown. See Appendix for full taxonomic designations. Seismic stratigraphic correlations are after Mountain, Miller, Blum, et al. (1994) except where noted in the text.

ized by Lenticulina spp. and A. wilcoxensis (Factor 2) and Osangularia spp. (Factor 4) (Fig. 10). Coeval abyssal Sites 390 and 613 contain a deeper $N$. truempyi-dominated biofacies (Factor 5) in the early to middle Eocene (see also Miller and Katz, 1987a). Bathyal biofacies on the New Jersey Transect shifted to a biofacies dominated by B. alazanensis (Factor 1), Osangularia spp. (Factor 4), and P. bulloides (Factor 3 ) by the late Eocene. Although we lack an abyssal late Eocene record, we believe that the major bathyal faunal change that occurred near the end of the middle Eocene on the New Jersey
Transect reflects a global event that is also recorded at other bathyal and abyssal sites (e.g., Katz and Miller, 1991; Thomas, 1990; Tjalsma and Lohmann, 1983). Miller et al. (1992) and Thomas (1992a) speculated that changing deep-water conditions associated with a late middle Eocene cooling (inferred from the $\delta^{18} \mathrm{O}$ record) triggered these faunal changes worldwide.

Late Eocene bathyal faunas on the New Jersey Transect contain high abundances of B. alazanensis (up to 50\%; Fig. 12B); similar coeval peak $B$. alazanensis abundances have been reported from the 


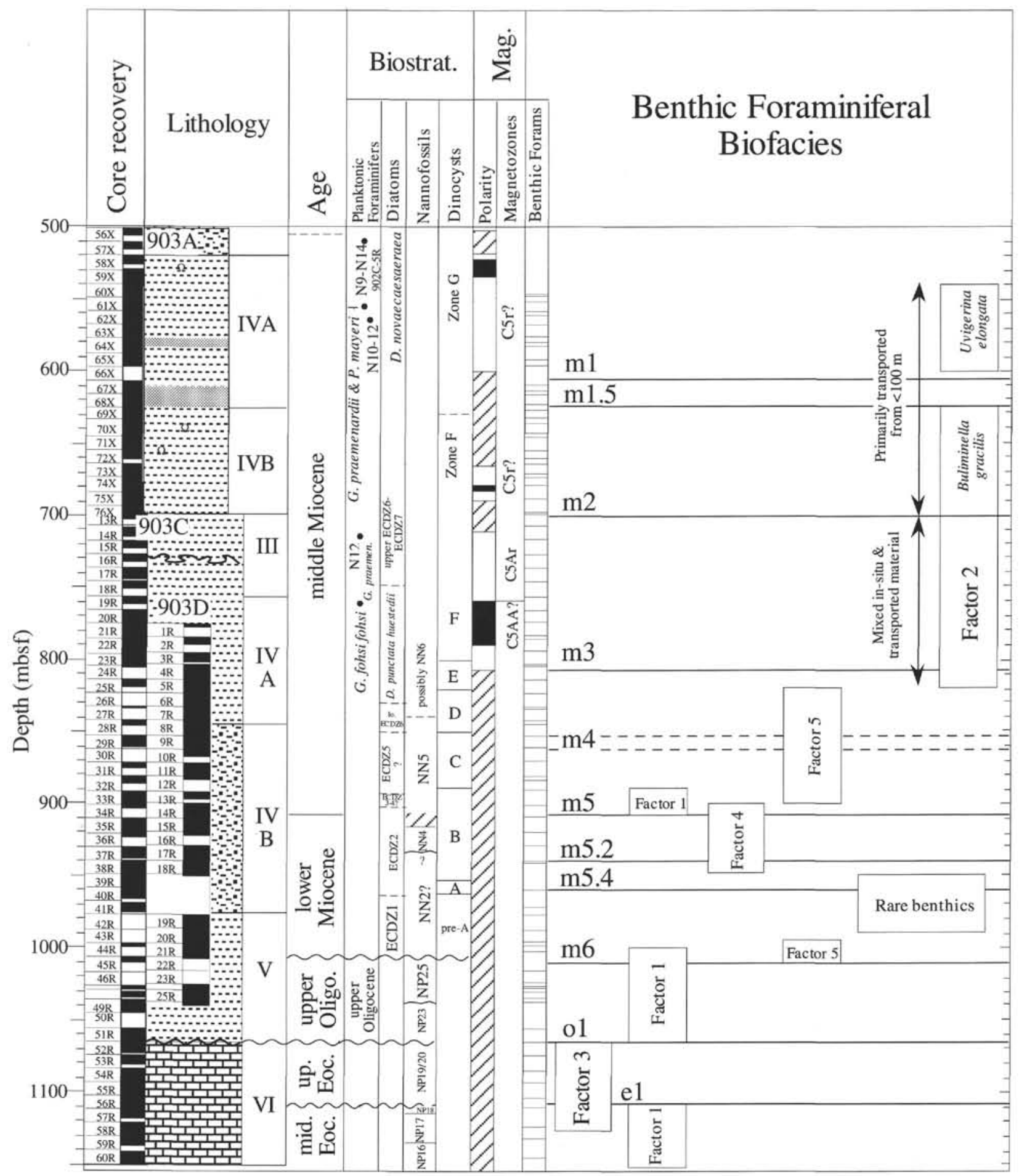

Figure 9. Site 903 biofacies represented by Q-mode varimax factors. Seismic stratigraphic correlations are after Mountain, Miller, Blum, et al. (1994) except where noted in the text. Biostratigraphy includes planktonic foraminifers (Snyder et al., this volume), nannofossils, diatoms, and dinocysts (Mountain, Miller, Blum, et al., 1994). Lithostratigraphy is after Mountain, Miller, Blum, et al. (1994). Magnetostratigraphy is after Van Fossen and Urbat (this volume).

Gulf of Mexico (E67-128, 1600 m paleodepth; B.H. Corliss, pers. comm., 1994). Increases in B. alazanensis abundances $(<15 \%)$ have been noted in other upper Eocene Atlantic sections: Site 516 (South Atlantic; $1000 \mathrm{~m}$ paleodepth; Tjalsma, 1983), Site 548 (Irish Margin; 1200 m paleodepth; Miller et al., 1985), Site 144 (east of Venezuela; $2500 \mathrm{~m}$ paleodepth; M.E. Katz, K.G. Miller, and R.C. Tjals- ma, unpubl. data, 1995), and Site 366 (Sierra Leone Rise; $2800 \mathrm{~m}$ paleodepth; M.E. Katz, K.G. Miller, and R.C. Tjalsma, unpubl. data, 1995). We speculate that this uniform late Eocene biofacies characterized by high abundances of $B$. alazanensis indicates that circumAtlantic sites were ventilated by similar intermediate to upper deepwater masses at this time. 




Figure 10. Eocene age-paleodepth bubble diagrams of Q-mode varimax factor combined data set loadings for the New Jersey Transect (ODP Sites 902, 903, 904, and 906 and DSDP Sites 108, 390, 612, and 613). Bubble size is proportional to each loading, with the maximum loading (largest bubble size) shown on each panel. Percentage of the faunal variation explained by each factor and the species with the highest scores on each factor are shown.

A cosmopolitan Lenticulina spp.-dominated biofacies prevailed in the Oligocene to early Miocene bathyal zone (note that we have no abyssal record for this interval); polymorphinids and $A$. wilcoxensis were common secondary components (Factor 1; Fig. 11). In addition, biofacies represented by Factors 4 (dominated by $U$. proboscidea, Plectofrondicularia spp., and $S$. modesta) and 5 (characterized by $M$. pompilioides, Stilostomella spp., M. barleeanum, P. bulloides, and Plectofrondicularia spp.) show high loadings during this interval. A $U$. hispida-B. alazanensis-dominated biofacies characterized the middle Miocene (Factor 3). A similar coeval shift from a Lenticulina spp.-dominated biofacies to a Uvigerina spp.-dominated biofacies occurred in the Gulf of Mexico (Katz and Miller, 1993), indicating that this Uvigerina increase may be regional in extent. The faunal shift from the Lenticulina spp.-dominated biofacies to the $U$. hispi$d a-B$. alazanensis-dominated biofacies may be the regional expression of a global late early to early middle Miocene benthic foraminiferal turnover event and associated abundance changes. Previous studies have speculated that this global middle Miocene benthic foraminiferal faunal event may have been related to changes in deepwater sources and/or surface ocean productivity (e.g., Miller and Katz, 1987b; Thomas and Vincent, 1987; Thomas, 1992b; Woodruff and Savin, 1989). Katz and Miller (1993) found that the increased uvigerinid flux in the Gulf of Mexico corresponds with increased organic carbon flux in middle Miocene sediments, indicating that surface ocean productivity may have been responsible at least in part for the global middle Miocene faunal event. Further supporting this, 

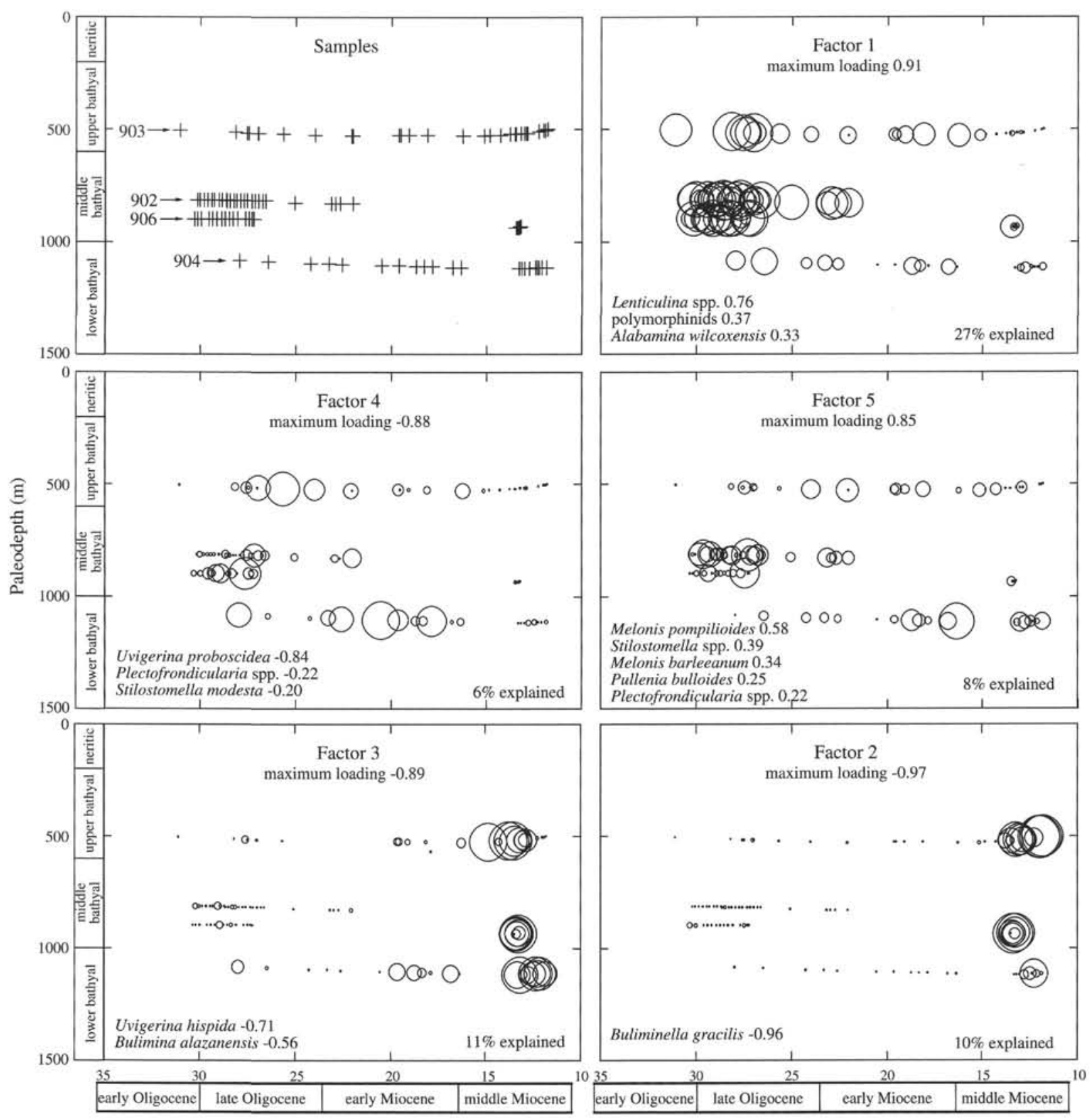

Age (Ma)

Figure 11. Oligocene to Miocene age-paleodepth bubble diagrams of Q-mode varimax factor combined data set loadings for the New Jersey Transect (ODP Sites 902, 903, 904, and 906 and DSDP Sites 108, 390, 612, and 613). Bubble size is proportional to each loading, with the maximum loading (largest bubble size) shown on each panel. Percentage of the faunal variation explained by each factor and the species with the highest scores on each factor are shown.

high abundances of Holocene Uvigerina spp. have been linked to a high supply of organic material to the sediments (see Thomas et al., 1995, for summary).

The Factor 2 allochthonous biofacies (characterized by Buliminella gracilis; Fig. 11) increased in dominance through the middle to late middle Miocene. A dramatic change occurred on the New Jersey slope between Reflectors $\mathrm{m} 3$ (13.5 Ma) and $\mathrm{m} 2$ (12.5 Ma), with a major increase in downslope transport of neritic (shelf) taxa (B. gracilis, $U$. elongata) (see below). This faunal change is associated with a dramatic increase in sedimentation rates $(>60 \mathrm{~cm} / \mathrm{yr})$, illustrated by the increase in thickness between Reflectors $\mathrm{m} 3$ and $\mathrm{m} 2$. This change in slope sedimentation style is associated with submarine channel cut- ting, high terrestrial carbon input, and mobilization of biogenic carbonate to form diagenetic nodules (Mountain, Miller, Blum, et al., 1994).

\section{Biofacies Changes Within a Sequence Stratigraphic Framework}

Benthic foraminiferal biofacies changes have proven to be useful in deciphering depositional sequences in shallow-water deposits (e.g., Olsson et al., 1987; Christensen et al., in press). To evaluate whether slope benthic foraminifers exhibit similar biofacies changes, we examined samples across the m5 sequence (ca. 16.5 to $15.8 \mathrm{Ma}$; 
A

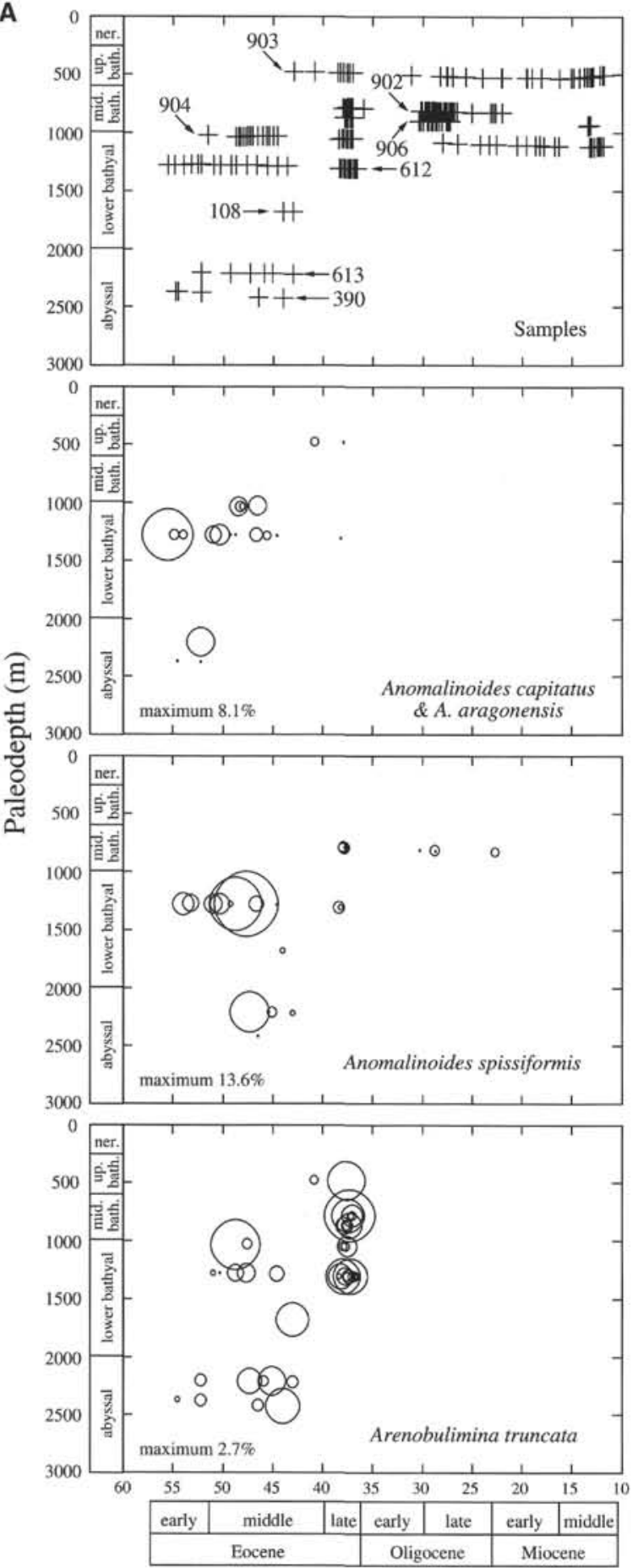

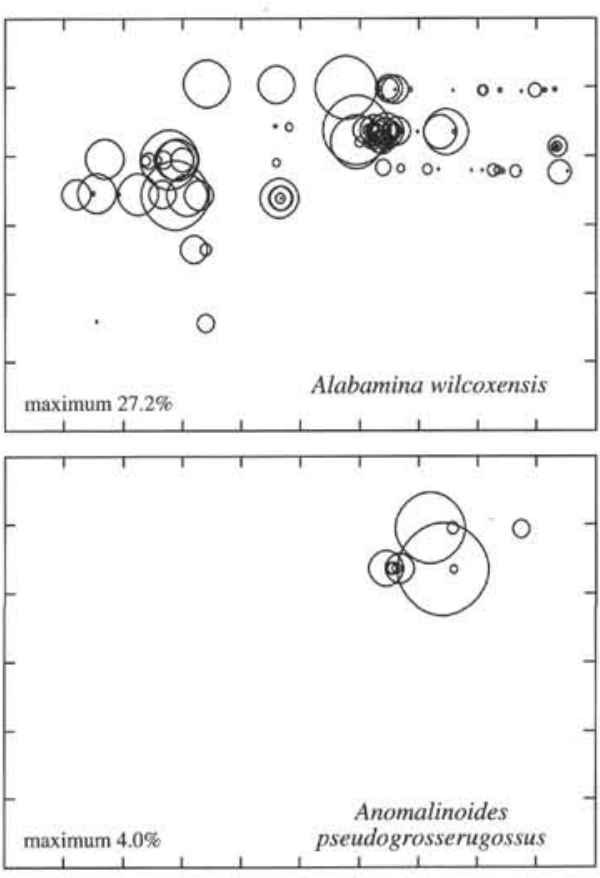
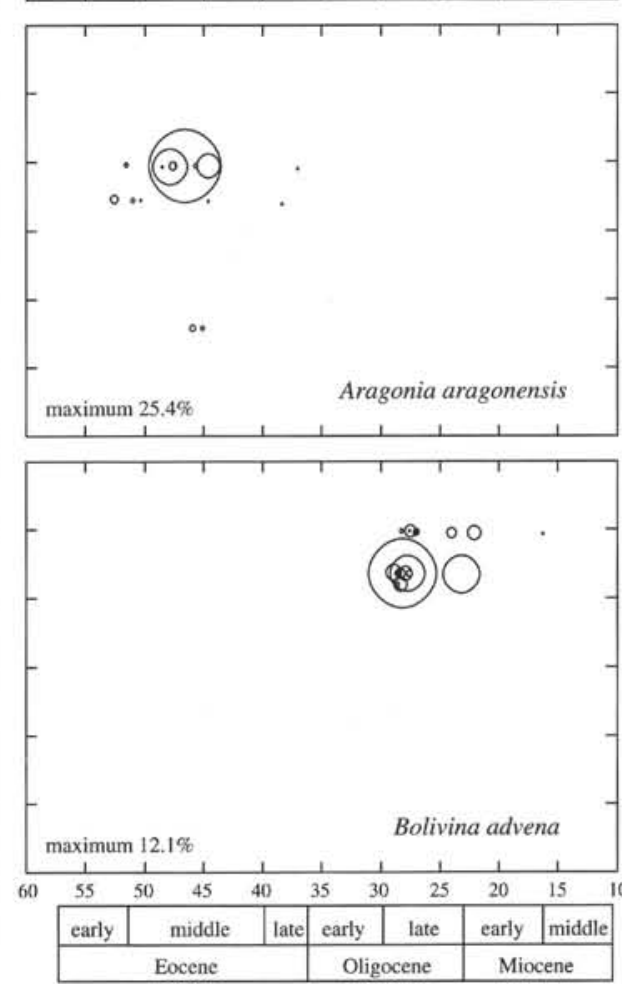

Age (Ma)

Figure 12. A-L. Eocene to Miocene age-paleodepth bubble diagrams of benthic foraminiferal species for the New Jersey Transect (ODP Sites 902, 903, 904, and 906 and DSDP Sites 108, 390,612, and 613). Bubble size is proportional to each species percentage; maximum species percentage (largest bubble size) is shown on each panel.

Miller et al., this volume) at Site 903 (40 samples between 839.28 and $921.09 \mathrm{mbsf}$ ) and at Site 904 ( 24 samples between 223.06 and 268.70 mbsf). The $\mathrm{m} 5$ sequence at Site 903 is bracketed by Reflector $\mathrm{m} 5$ ( 908.4 mbsf) below and Reflector m4 (between 852 and 862 mbsf) above. The $\mathrm{m} 4$ sequence is missing at Site 904 ; here, the $\mathrm{m} 5$ sequence is bracketed by Reflector $\mathrm{m} 5$ ( $264.2 \mathrm{mbsf}$ ) below and Reflector $\mathrm{m} 3$ (244 mbsf) above (Figs. 13, 14).
We evaluated benthic foraminiferal absolute (number per gram) and relative abundance changes within the sequence stratigraphic framework outlined above. No good correlation was found between the number of benthic foraminifers per gram and sequences (Figs. 13, 14). However, several species relative abundance changes appear to be related to sequence boundaries. Melonis pompilioides shows higher percentages across the boundaries, whereas total Stilostomella spp. 
B



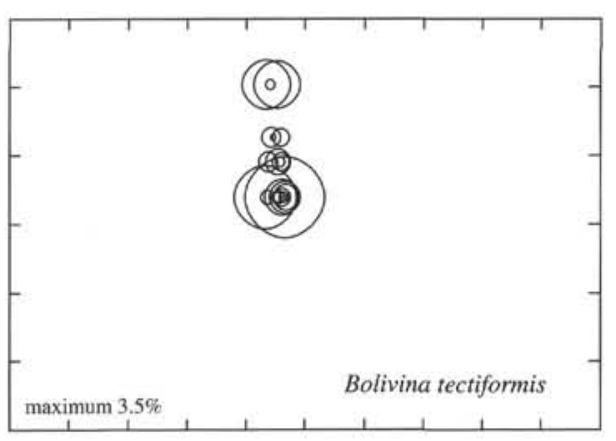

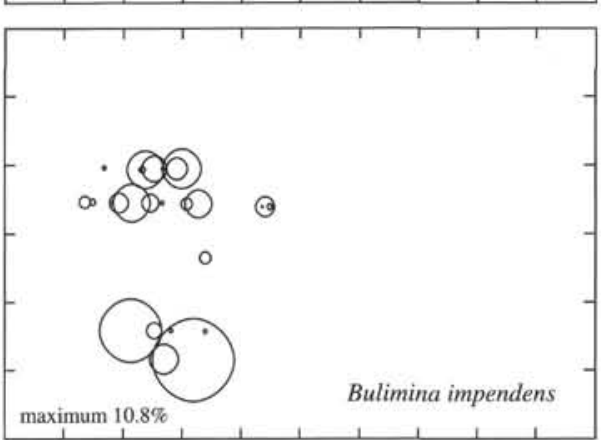

maximum $10.8 \%$


(Ma)

Figure 12 (continued).

increases immediately below the boundaries at Site 903 (Fig. 13); these patterns are not observed at the deeper Site 904 (Fig. 14). However, U. proboscidea increases above Reflector $\mathrm{m} 5$ at both sites, and above Reflector $\mathrm{m} 4$ at Site 903 (note that the corresponding $\mathrm{m} 4$ sequence is absent at Site 904) (Figs. 13,14). We interpret $U$. proboscidea as in situ, indicating that the dominant biofacies immediately above the reflectors and correlative sequence boundaries are not transported (1.7 $\mathrm{m}$ above $\mathrm{m} 5$ and $0.5 \mathrm{~m}$ above $\mathrm{m} 4$ at Site $903 ; 1.5 \mathrm{~m}$ above $\mathrm{m} 5$ at Site 904). Based on the higher abundances of $U$. proboscidea immediately above sequence boundaries, we suggest that Reflector $\mathrm{m} 4$ corresponds to $862 \mathrm{mbsf}$ at Site 903 . This level corresponds to the base of a minor lithologic color change (Mountain, Miller, Blum, et al., 1994).

Although the dominant benthic foraminifers are in situ, there is limited evidence of shelf transport in the $\mathrm{m} 5$ to $\mathrm{m} 3$ interval. We consider Buliminella gracilis and Nonionella pizarrensis to be down- 


\section{C}
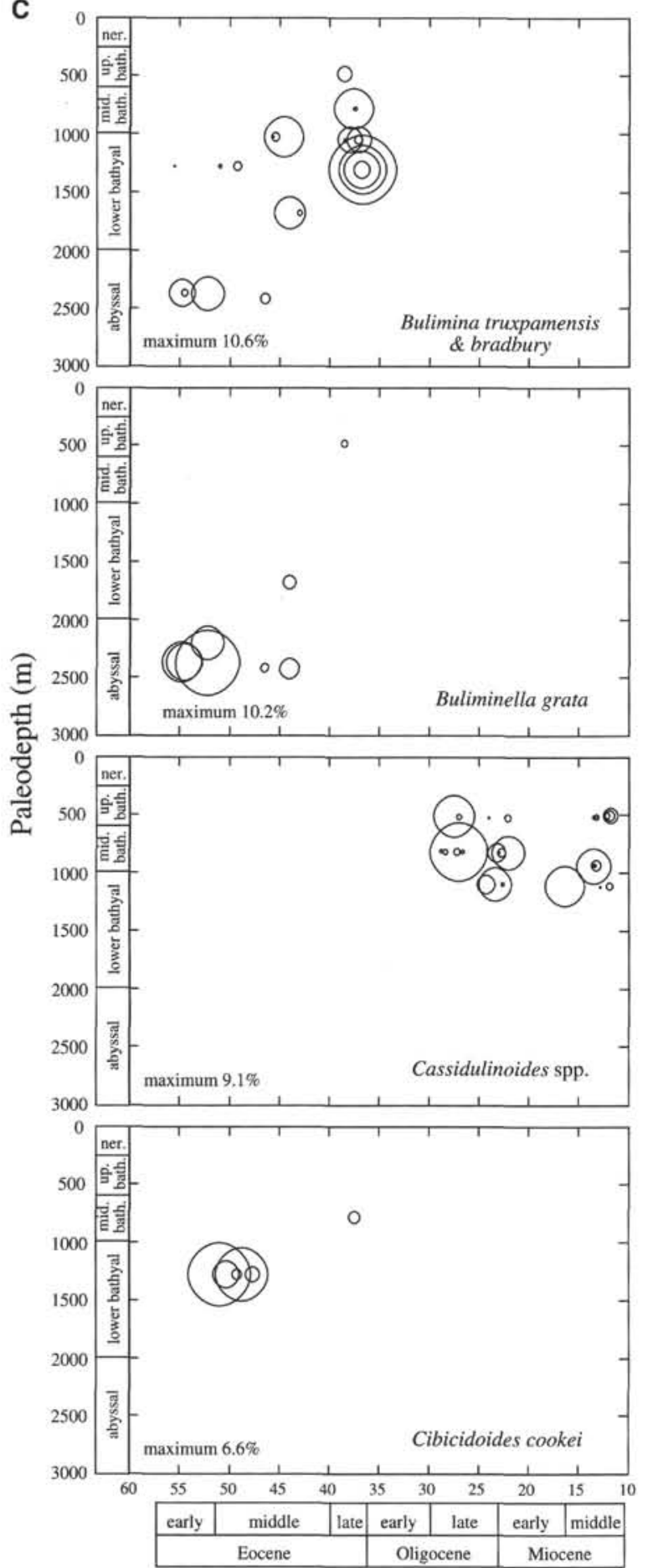
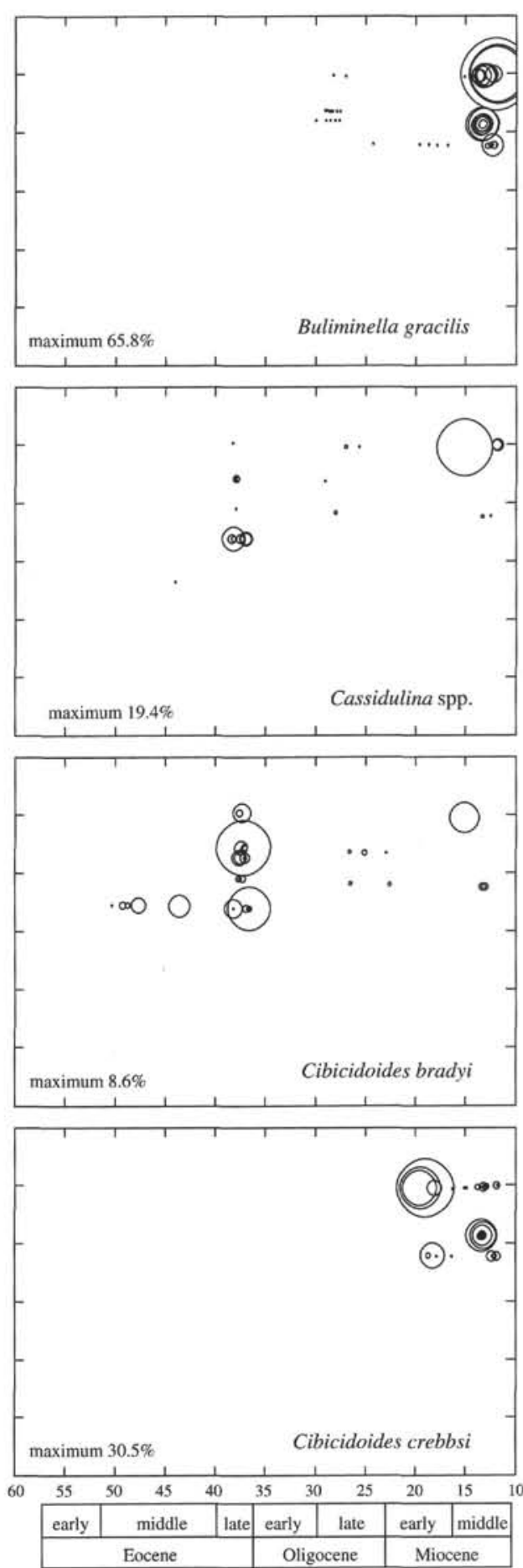

Age (Ma)

Figure 12 (continued).

slope-transport indicators because they typify Oligocene to Pliocene inner neritic environments on the mid-Atlantic United States margin (Gibson, 1972; Olsson et al., 1980; Poag, 1978). Neither taxon is as abundant in the $\mathrm{m} 5-\mathrm{m} 3$ interval as in the overlying upper middle Miocene and younger sections, where the dominant mode of sedimentation is downslope transport (Mountain, Miller, Blum, et al., 1994; Christensen et al., this volume; this study, see below). At the shallower Site $903, N$. pizarrensis is most abundant above and below
Reflector m5, whereas B. gracilis is most abundant across Reflector $\mathrm{m} 4$ (Fig. 13). However, both taxa decrease immediately below the unconformities and show abundance peaks immediately above them. Similarly, $N$. pizarrensis decreases immediately below Reflector m5 at Site 904 and peaks immediately above it (Fig. 14). Thus, B. gracilis and $N$. pizarrensis occur in greatest abundances both above several sequence boundaries and in the upper parts of several sequences (Figs. 13, 14). This evidence for downslope transport, albeit a minor 

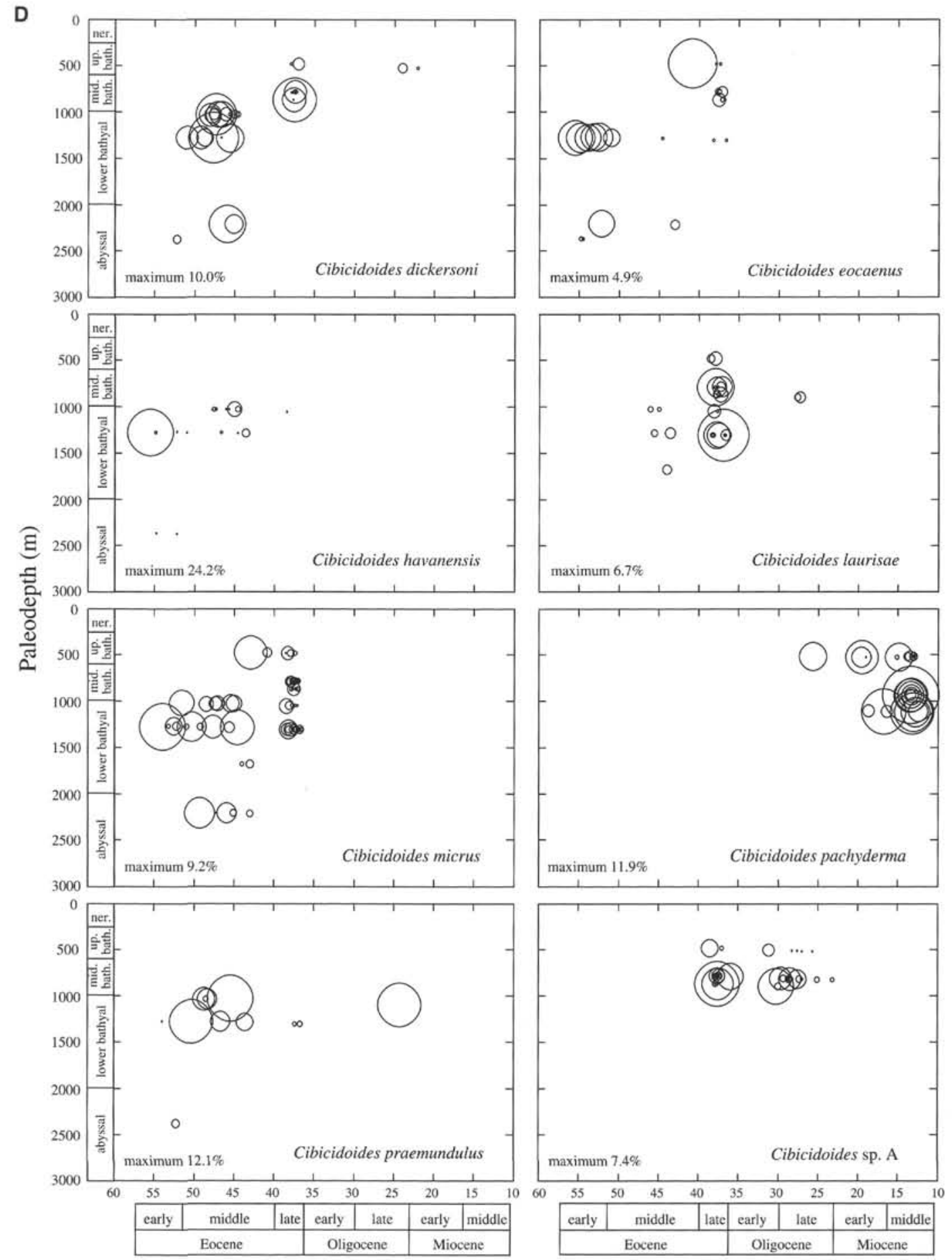

Age (Ma)

Figure 12 (continued).

component, is consistent with shipboard interpretations that noted that downslope-transported sediments occur immediately above sequence boundaries. Shallow-water taxa that occur high up in the underlying sequence may reflect downslope transport that first appears in the upper parts of sequences, correlative with the upper highstand systems tracts on the shelf (i.e., during maximum shelf progradation).

We conclude that benthic foraminiferal biofacies changes at the slope sites exhibit sequence stratigraphic variations in addition to global benthic foraminiferal changes. Although expression of slope systems tracts and stratal surfaces is not as obvious as in shallowwater sections (e.g., Loutit et al., 1988), there is benthic foraminiferal evidence for (1) downslope-transported shelf material above several sequence boundaries and in the upper parts of several sequences; (2) a preponderance of $U$. proboscidea in the lower parts of several sequences, which may be the slope equivalent of the shelf lowstand systems tract; (3) Stilostomella spp. are more abundant in the upper parts 
E

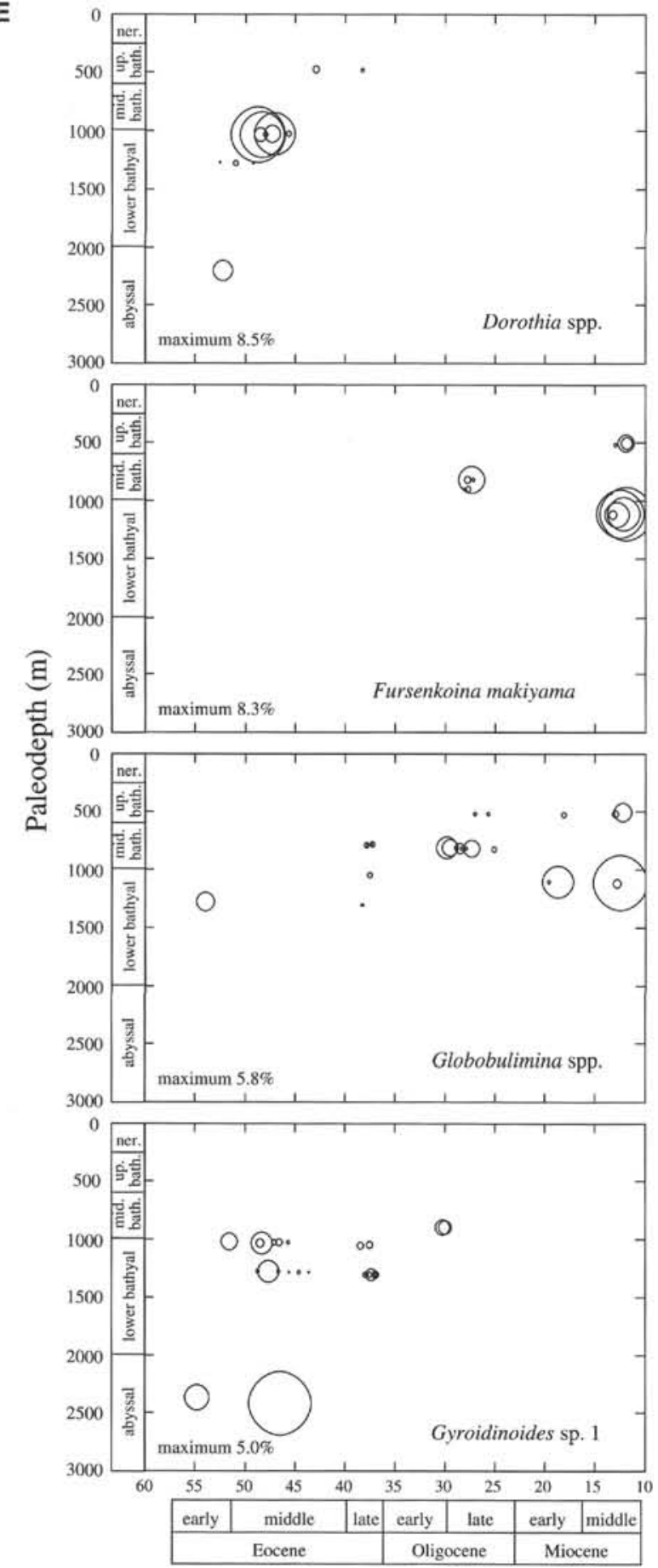

Age (Ma)

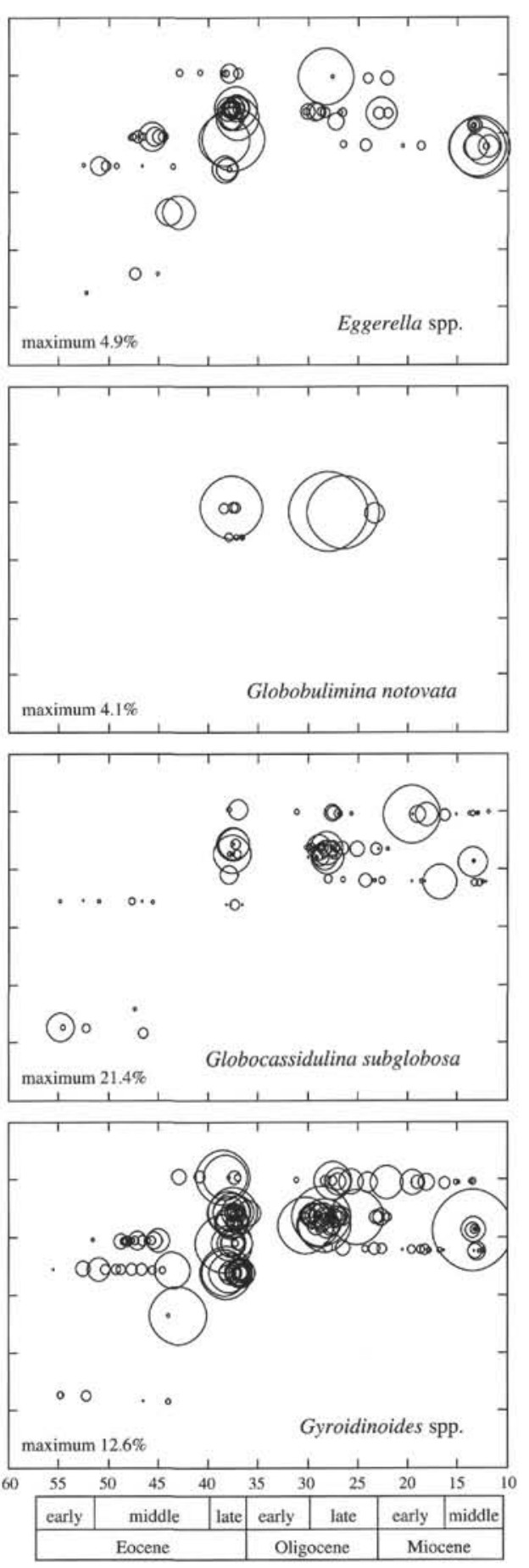

Figure 12 (continued).

of several sequences, which may be the slope equivalent of the shelf highstand systems tracts; and (4) more abundant $M$. pompilioides spanning several sequence boundaries. The sections immediately above sequence boundaries that contain predominantly in situ faunas with minor abundances of transported benthic foraminifers $(<10 \%$ of the total fauna) may correlate to the lowstand systems tracts on the shelf. Minor abundances of transported benthic foraminifers reappear in the upper parts of several sequences, and may reflect minor shed- ding of shelf sediments during highstand systems tracts progradation on the shelf.

\section{Transport and Sedimentation}

Benthic foraminifers indicate that sedimentation was primarily in situ at our slope sites in the Eocene to early Miocene. All of the Eocene sections recovered yield in situ faunas, in agreement with 


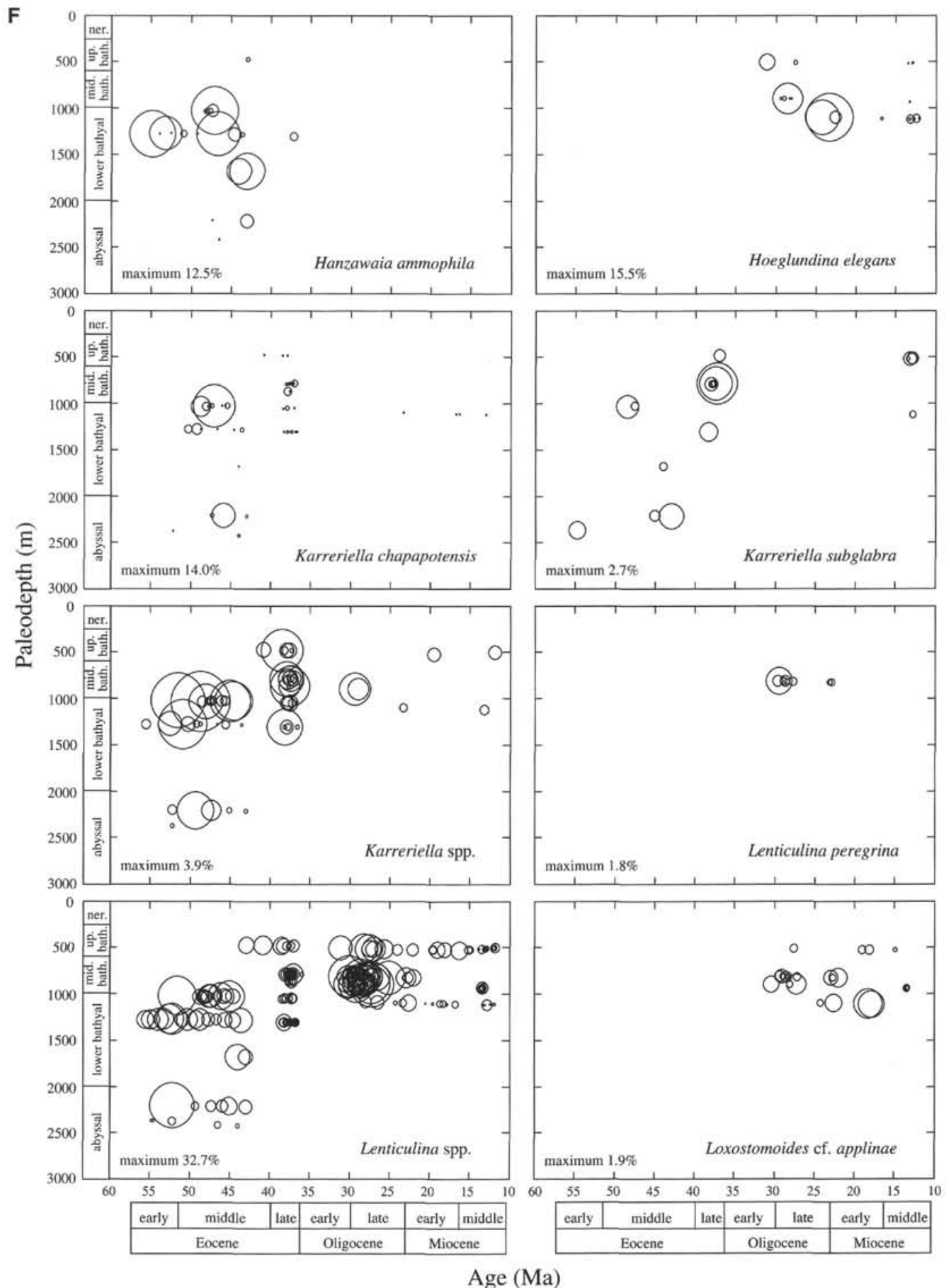

Figure 12 (continued).

previous studies at Sites 108, 390, 612, and 613 (Miller and Katz, 1987a). Transported biofacies are minimal in the Oligocene to lower middle Miocene sections at Sites 902, 903, 904, and 906, documenting for the first time that "quiescent" sedimentation continued in the region of our New Jersey slope sites well into the Neogene.

A dramatic change in the dominant mode of sedimentation occurred in the middle Miocene in our study area. At Sites 903 and 904 , abundant downslope transport of shelf taxa (B. gracilis, U. elongata) appears between Reflectors m3 (13.5 Ma) and m2 (12.5 Ma) (Fig. 15). Buliminella gracilis comprises nearly $100 \%$ of the faunas in the middle middle Miocene and $U$. elongata comprises nearly $100 \%$ of the faunas in the upper middle Miocene at Site 903 (Fig. 9). Buliminella gracilis comprises up to $50 \%$ of the upper middle to upper Miocene faunas at Site 904, but it is not as abundant as at the shallower Site 903 (Fig. 15), reflecting its greater distance from the sediment source. The extent of the downslope transport increases from 


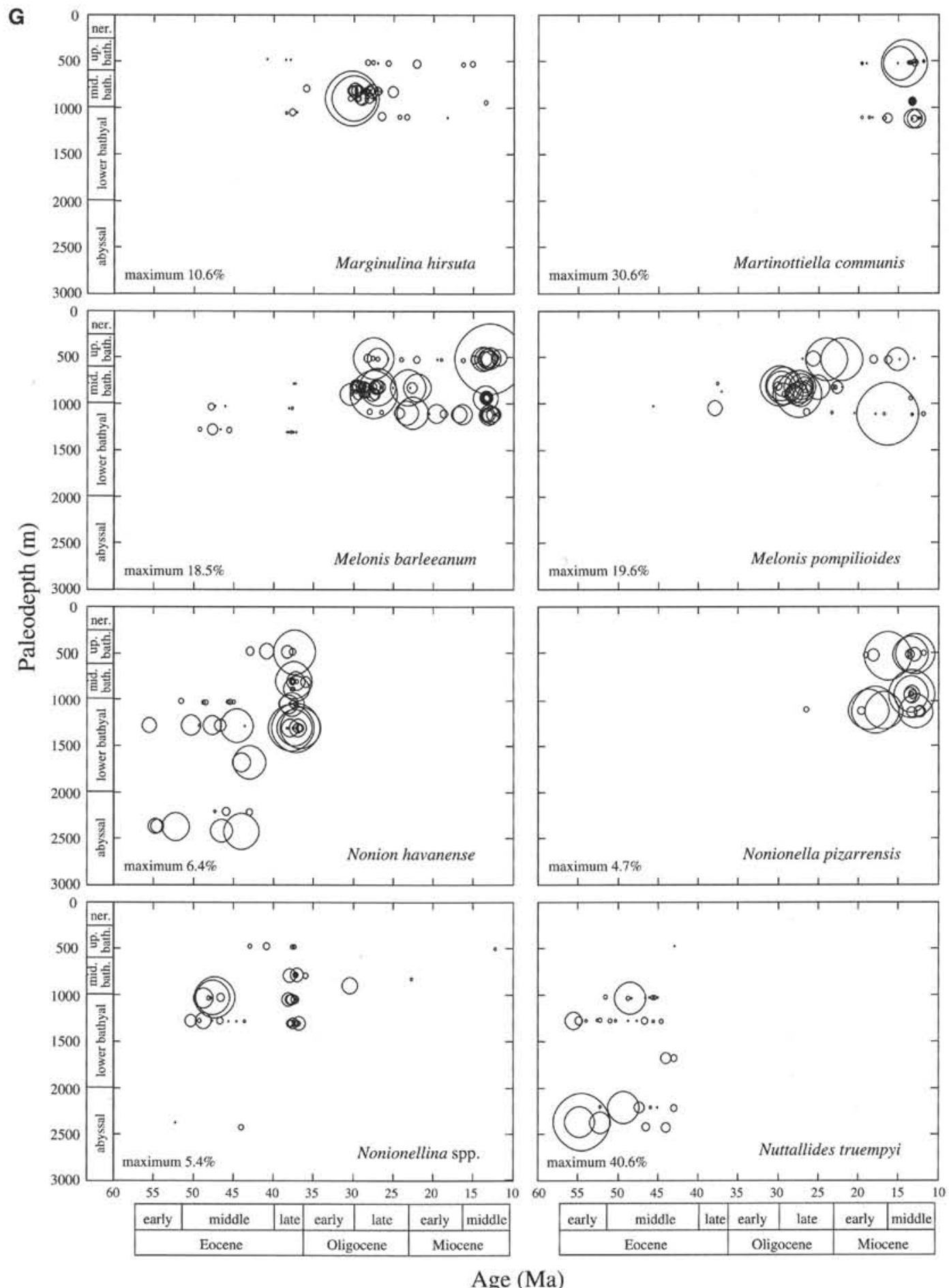

Figure 12 (continued).

$<30 \%$ in the $\mathrm{m} 2$ sequence at Site 904 to $>50 \%$ in the $\mathrm{ml}(11.3-10.6$ $\mathrm{Ma}$ ) and younger sequences. The switch to dominant downslope transport at Site 904 occurred $\sim 2$ m.y. later than at Site 903 because Site 903 is more proximal to the source area. The corresponding upper middle to lower upper Miocene section at Site 902 contains no carbonate fossils, but does contain silts and clays with abundant plant and wood fragments accumulated at high rates; the input of this terrigenous debris also began at about Reflector $\mathrm{m} 3$ time $(13.5 \mathrm{Ma})$ at this site (Mountain, Miller, Blum, et al., 1994), concurrent with the time of canyon cutting at Site 906 (Mountain, Miller, Blum, et al., 1994; Mountain et al., this volume).

The coincident increase in transported neritic benthic foraminifers, the increase in terrigenous supply, and the first major Miocene slope canyon cutting event (Mountain, this volume) at $13.5 \mathrm{Ma}$ are attributed to increased delivery of sediments to the slope from the shelf. This is indicated by seismic profiles that show that by about $13.5 \mathrm{Ma}$, 

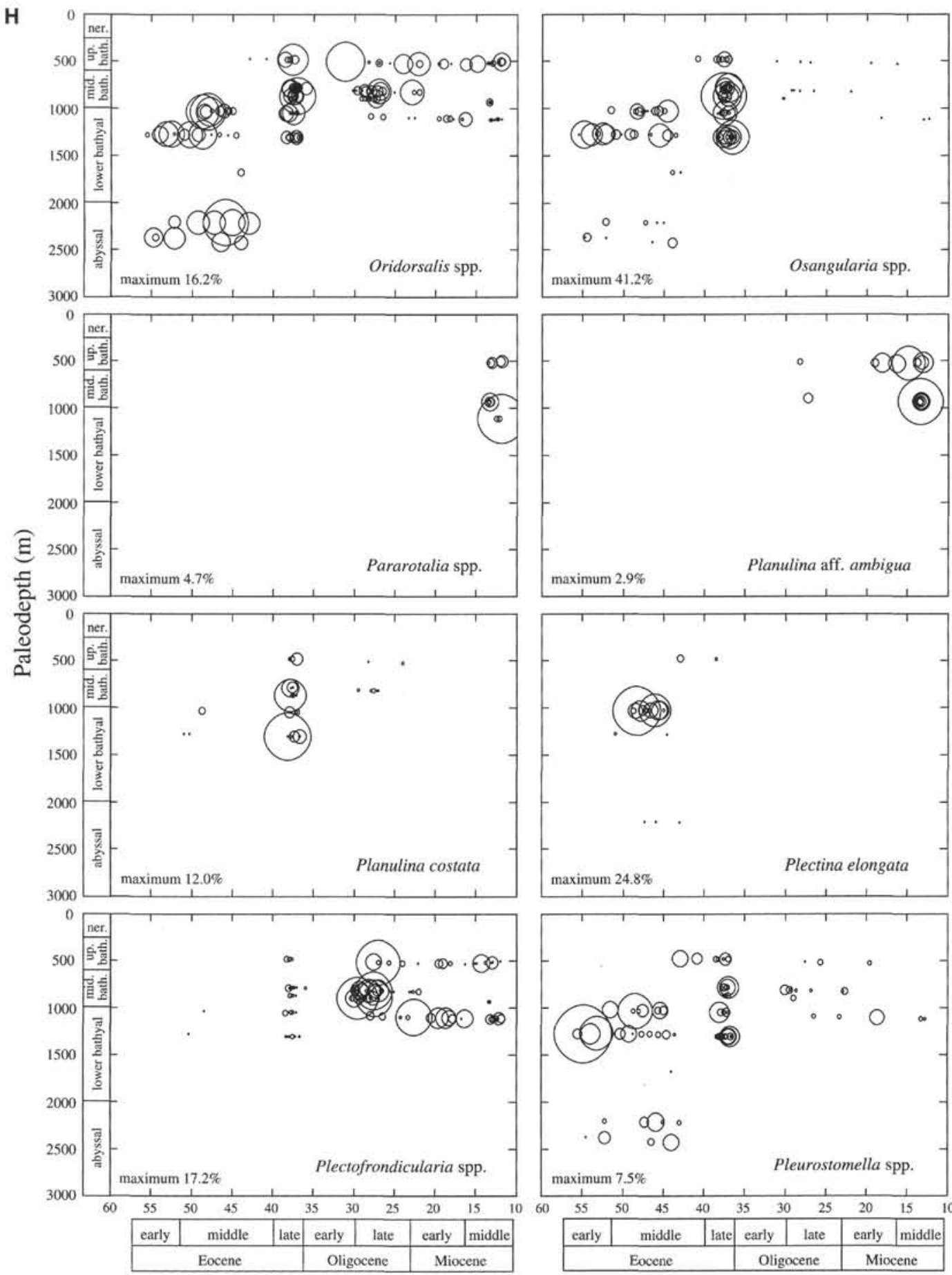

Age (Ma)

Figure 12 (continued).

clinoforms prograded from a location that is beneath the modern middle shelf to one that is beneath the modern outer shelf (Mountain, Miller, Blum, et al., 1994). Increased downslope transport accompanied the progradation of clinoforms from $90 \mathrm{~km}$ landward of Site 903 in the early Miocene (Reflectors m6-m5; see cross section in Mountain, Miller, Blum, et al., 1994) to $\sim 60 \mathrm{~km}$ landward in the middle Miocene (Reflectors $\mathrm{m} 4-\mathrm{ml}$ ). In addition, this was the time of major glacioeustatic lowerings (i.e., the Mi3 oxygen isotopic event of Mill- er et al., 1991) and development of the permanent Antarctic Ice Sheet (Shackleton and Kennett, 1975), reducing the available accommodation space on the shelf and contributing to the increase in terrigenous flux to the slope. Transported neritic benthic foraminifers dominate the upper Miocene to the Pleistocene section (Christensen et al., this volume), reflecting the shedding of shelf sediments to the slope as clinoforms prograded to less than $20 \mathrm{~km}$ landward of Site 903 in the Pleistocene (Reflectors p6-p1). The benthic foraminiferal biofacies 

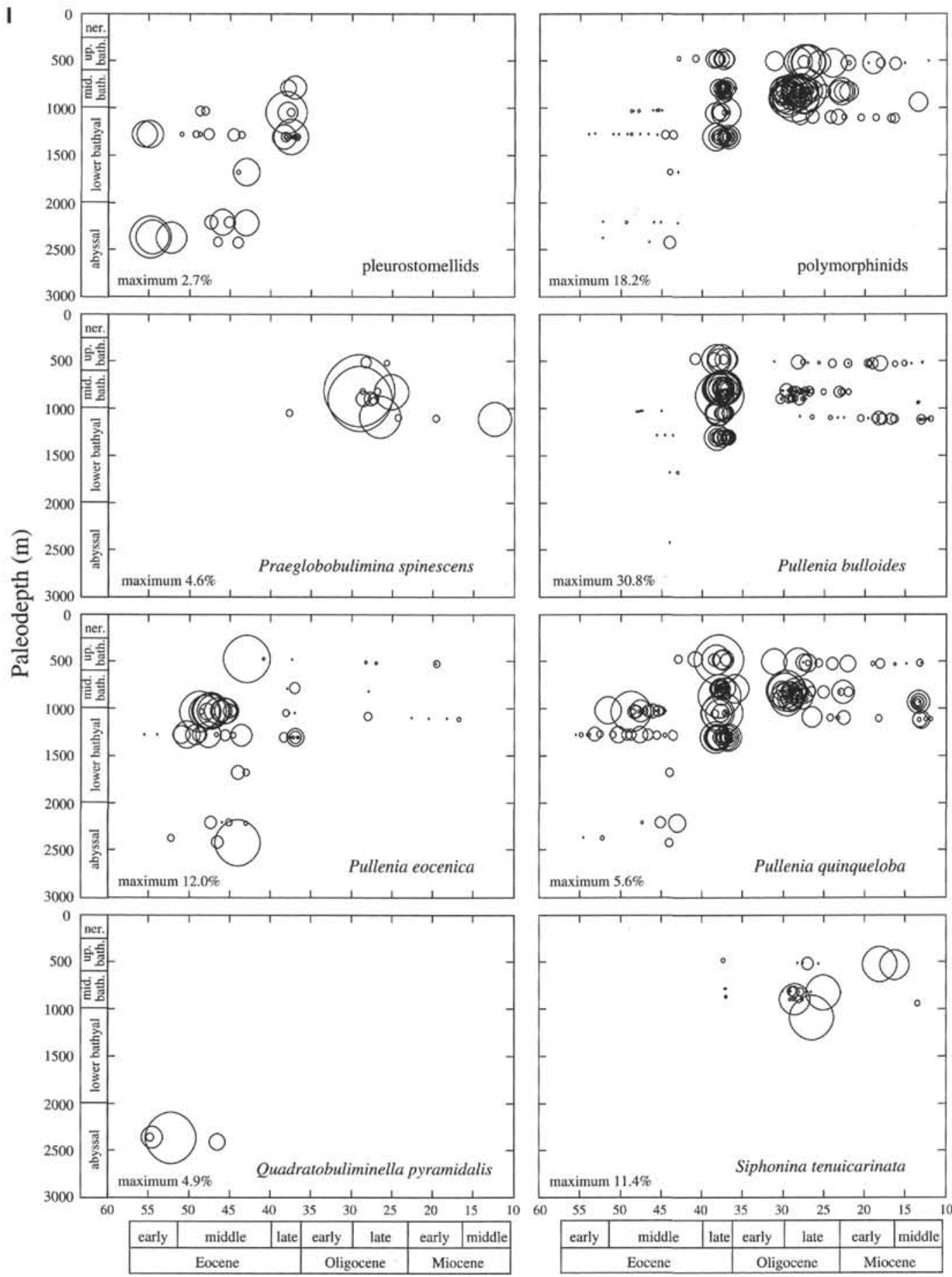

Age (Ma)

Figure 12 (continued).

changes at the sites studied here reflect the evolution from an Eocene carbonate-dominated ramp-type shelf and slope, to an Oligocene starved margin (both with in situ biofacies), to a prograding Miocene and younger siliciclastic-dominated margin (with progressive influence of allochthonous facies).

\section{SUMMARY AND CONCLUSIONS}

Eocene to early middle Miocene benthic foraminifers on the New Jersey Transect comprise generally cosmopolitan deep-water faunas, and biofacies changes primarily reflect global and regional paleoceanographic changes:

1. A bathyal biofacies shift occurred between the middle and late Eocene, correlating with a global bathyal-abyssal change associated with a late middle Eocene cooling event (e.g., Tjalsma and Lohmann, 1983; Miller et al., 1992; Thomas, 1992a).

2. Uniform late Eocene B. alazanensis biofacies on the New Jersey slope, in the Gulf of Mexico, and other Atlantic locations indicates that circum-Atlantic sites were ventilated by similar intermediate to upper deep-water masses at this time. 



Age (Ma)

Figure 12 (continued).

3. A cosmopolitan Lenticulina spp. biofacies that dominated the Oligocene to middle Miocene bathyal zone was replaced by a $U$. hispida- $B$. alazanensis-dominated biofacies in the middle Miocene, correlating with a similar increase in Uvigerina spp. in the Gulf of Mexico. The faunal shift may be the regional expression of a global late early to early middle Miocene benthic foraminiferal event related to changes in deep-water sources and/or surface ocean productivity.

In addition to global and regional faunal changes, benthic foraminiferal biofacies changes at the Leg 150 slope sites exhibit varia- tions related to sequence stratigraphy: (1) there is downslope-transported shelf material above several sequence boundaries (may represent the slope expression of the shelf lowstand systems tracts) and in the upper parts of several sequences (within the slope equivalent of the shelf highstand systems tracts); (2) there is a preponderance of $U$. proboscidea in the lower parts of several sequences, which may represent in situ biofacies within the slope expression of the lowstand systems tracts; (3) Stilostomella spp. are more abundant in the upper parts of several sequences, which may be equivalent to the shelf highstand systems tracts; and (4) $M$. pompilioides is more abundant span- 



Age (Ma)

Figure 12 (continued).

ning several sequence boundaries. Sections immediately above sequence boundaries that contain predominantly in situ faunas with minor abundances of transported benthic foraminifers $(<10 \%$ of the total fauna) may correlate to the shelf lowstand systems tracts. Upper parts of several sequences contain minor abundances of transported benthic foraminifers and may reflect minor shedding of shelf sediments during highstand systems tracts progradation on the shelf.

Allochthonous facies are minimal in the Eocene to lower Miocene sections cored by Leg 150 and the dominant pattern of sedimentation was (hemi-)pelagic settling, as it is today. There is limited evidence for downslope transport in the lower middle Miocene m5-m3 interval. A dramatic change in the dominant mode of sedimentation began at our New Jersey slope sites between Reflectors m3 (13.5 Ma) and $\mathrm{m} 2(12.5 \mathrm{Ma})$, with a major increase in downslope transport of neritic (shelf) taxa $(B$. gracilis, $U$. elongata) that continued through the Pleistocene. This increase in transported fauna is associated with dramatically increased sedimentation rates $(>60 \mathrm{~cm} / \mathrm{yr})$, submarine channel cutting, and high terrestrial input that accompanied the pro- 

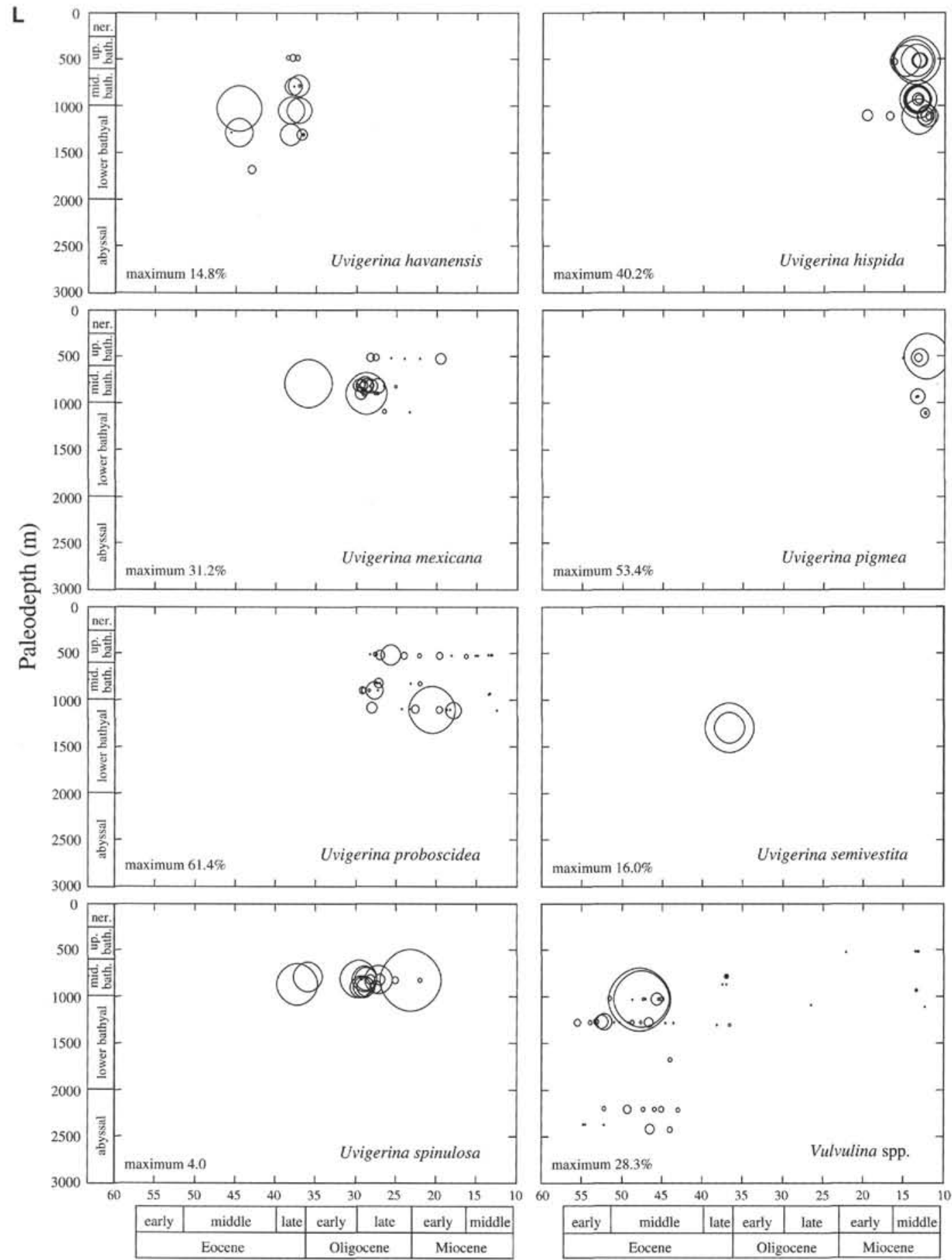

Age (Ma)

Figure 12 (continued).

gradation of clinoforms from $90 \mathrm{~km}$ landward of Site 903 in the early Miocene to less than $20 \mathrm{~km}$ landward in the Pleistocene.

\section{ACKNOWLEDGMENTS}

We thank our Leg 150 colleagues for providing data, particularly B. Christensen, J. Lorenzo, G. Mountain, S. Snyder, M. Urbat, and
M. Van Fossen. We thank M. Steckler for the backstripped paleodepths. We thank G. Jones, C.W. Poag, E. Thomas, and an anonymous reviewer for comments on the manuscript. Samples were provided by the Ocean Drilling Program. This study was supported by a consortium of oil companies (British Petroleum, Chevron, Exxon, Marathon, and UNOCAL), JOI/USSAC, and NSF grant OCE9203282 (Mountain, Miller). This is Lamont-Doherty Earth Observatory contribution number 5507 . 




Figure 13. Detailed section across the m5 sequence at Site 903 showing the number of benthic foraminifers per gram and selected species percentages within a sequence stratigraphic framework. Shaded area represents the uncertainty in the placement of Reflector m4. Reflectors $\mathrm{m} 4$ (852-862 mbsf) and m5 ( 908.4 mbsf) correspond to sequence boundaries. LST $=$ lowstand systems tracts; TST = transgressive systems tracts; and HST $=$ highstand systems tracts. Ages are derived from $\mathrm{Sr}$ isotope stratigraphy (Miller et al., this volume).

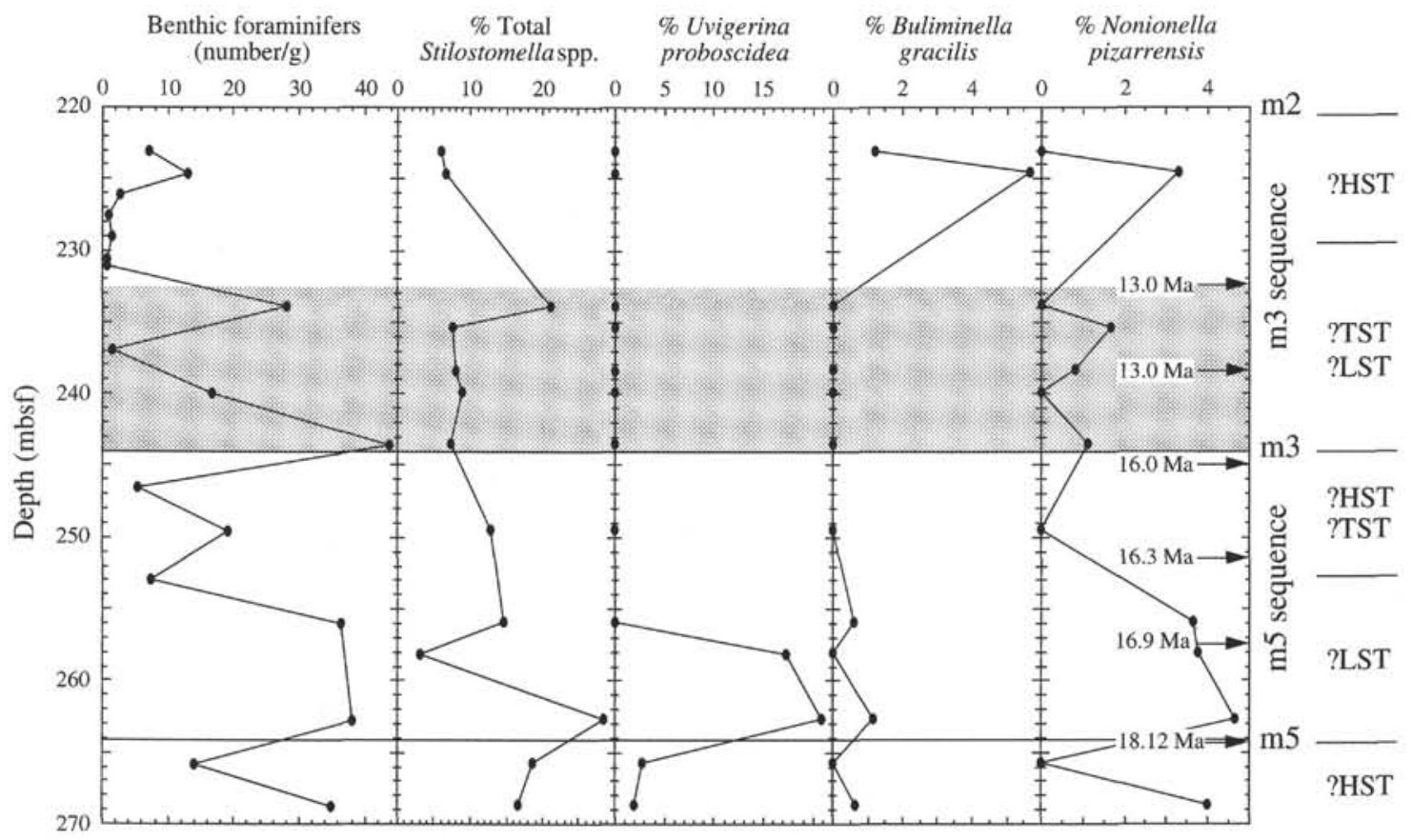

Figure 14. Detailed section across the m5 sequence at Site 904 showing the number of benthic foraminifers per gram and selected species percentages within a sequence stratigraphic framework. Shaded area represents the uncertainty in the placement of Reflector m3. Reflectors m2 (220 mbsf), m3 (232.5-244 mbsf), and $\mathrm{m} 5(264.2 \mathrm{mbsf})$ correspond to sequence boundaries. LST $=$ lowstand systems tracts; $\mathrm{TST}=$ transgressive systems tracts; and HST $=$ highstand systems tracts. Ages are derived from $\mathrm{Sr}$ isotope stratigraphy (Miller et al., this volume).

\section{REFERENCES}

Bandy, O.L., 1960. General correlation of foraminiferal structure with environment. Rep. Int. Geol. Congr., 21st Sess., Pt. 22:7-19.

Benson, W.E., Sheridan, R.E., et al., 1978. Init. Repts. DSDP, 44: Washington (U.S. Govt. Printing Office).
Berger, W.H., and Winterer, E.L., 1974. Plate stratigraphy and the fluctuating carbonate line. In Hsü, K.J., and Jenkyns, H.C. (Eds.), Pelagic Sediments on Land and Under the Sea. Spec. Publ. Int. Assoc. Sedimentol., 1:11-48.

Berggren, W.A., Kent, D.V., Flynn, J.J., and Van Couvering, J.A., 1985. Cenozoic geochronology. Geol. Soc. Am. Bull., 96:1407-1418. 
Berggren, W.A., Kent, D.V., Swisher, C.C., III, and Aubry, M.-P., 1995. A revised Cenozoic geochronology and chronostratigraphy. In Berggren, W.A., Kent, D.V., and Hardenbol, J. (Eds.), Geochronology, Time Scales, and Global Stratigraphic Correlations: A Unified Temporal Framework for an Historical Geology. Spec. Publ-—Soc. Econ. Paleontol. Mineral., 54.

Berggren, W.A., and Miller, K.G., 1989. Cenozoic bathyal and abyssal calcareous benthic foraminiferal zonations. Micropaleontology, 35:308320 .

Boersma, A., 1984. A Handbook of Common Tertiary Uvigerina: Stony Point, NY (Microclimates Press).

Bremer, M.L., and Lohmann, G.P., 1982. Evidence for primary control of the distribution of certain Atlantic Ocean benthonic foraminifera by degree of carbonate saturation. Deep-Sea Res. Part A, 29:987-988.

Brunner, C.A., and Culver, S.J., 1992. Quaternary foraminifera from the walls of Wilmington, South Wilmington, and North Heyes Canyon, U.S. East Coast: implications for continental slope and rise evolution. Palaios, 7:34-66.

Cande, S.C., and Kent, D.V., 1992. A new geomagnetic polarity time scale for the Late Cretaceous and Cenozoic. J. Geophys. Res., 97:1391713951.

Christensen, B.A., and Miller, K.G., 1991. Benthic foraminiferal distributions and Plio-Pleistocene to Recent sedimentation on the NJ slope and upper rise. Eos, 72:165.

Christensen, B.A., Miller, K.G., and Olsson, R.K., in press. Eocene-Oligocene benthic foraminiferal biofacies and depositional sequence at the ACGS\#4 borehole, New Jersey coastal plain. Palaios.

Gibson, T.G., 1972. Stratigraphy and paleoenvironment of the phosphate Miocene strata of North Carolina. Geol. Soc. Am. Bull., 78:632-649.

Greenlee, S.M., Devlin, W.J., Miller, K.G., Mountain, G.S., and Flemings, P.B., 1992. Integrated sequence stratigraphy of Neogene deposits, New Jersey continental shelf and slope: comparison with the Exxon model. Geol. Soc. Am. Bull., 104:1403-1411.

Grow, J.A., and Sheridan, R.E., 1988. U.S. Atlantic continental margin; a typical Atlantic-type or passive continental margin. In Sheridan, R.E., and Grow, J.A. (Eds.), The Atlantic Continental Margin: U.S. Geol. Soc. Am., Geol. of North Am. Ser., 1-7.

Hollister, C.D., Ewing, J.I., et al., 1972. Init. Repts. DSDP, 11: Washington (U.S. Govt. Printing Office).

Katz, M.E., and Miller, K.G., 1991. Early Paleogene benthic foraminiferal assemblages and stable isotopes in the Southern Ocean. In Ciesielski, P.F., Kristoffersen, Y., et al., Proc. ODP, Sci. Results, 114: College Station, TX (Ocean Drilling Program), 481-512.

, 1993. Latest Oligocene to earliest Pliocene benthic foraminiferal biofacies of the northeastern Gulf of Mexico. Micropaleontology, 39:367-403.

Kominz, M.A., 1984. Oceanic ridge volumes and sea-level change-an error analysis. In Schlee, J.S. (Ed.), Interregional Unconformities and Hydrocarbon Accumulation. AAPG Mem., 36:37-58.

Lohmann, G.P., 1980. PATS-1, a package of programs for the analysis of marine micropaleontological data on the VAX 11/780 computer. Woods Hole Oceanogr. Inst. Tech. Rept., WHOI-80-27.

Loutit, T.S., Hardenbol, J., Vail, P.R. and Baum, G.R., 1988. Condensed sections: the key to age determination and correlation of continental margin sequences. In Wilgus, C.K., Hastings, B.S., Ross, C.A., Posamentier, H.W., Van Wagoner, J., and Kendall, C.G.St.C. (Eds.), Sea-Level Changes: An Integrated Approach. Spec. Publ.-Soc. Econ. Paleontol. Mineral., 42:183-213.

Mazzullo, J., 1986. Sources of sand for the Mississippi Fan. In Bouma, A.H., Coleman, J.M., Meyer, A.W., et al., Init. Repts. DSDP, 96: Washington (U.S. Govt. Printing Office), 533-539.

Miller, K.G., Curry, W.B., and Ostermann, D.R., 1985. Late Paleogene (Eocene to Oligocene) benthic foraminiferal oceanography of the Goban Spur region, Deep Sea Drilling Project Leg 80. In de Graciansky, P.C., Poag, C.W., et al., Init. Repts. DSDP, 80: Washington (U.S. Govt. Printing Office), 505-538.

Miller, K.G., et al., 1994. Proc. ODP, Init. Repts., 150X: College Station, TX (Ocean Drilling Program).

Miller, K.G., and Katz, M.E., 1987a. Eocene benthic foraminiferal biofacies of the New Jersey Transect. In Poag, C.W., Watts, A.B., et al., Init. Repts. DSDP, 95: Washington (U.S. Govt. Printing Office), 267-298.

1987b. Oligocene to Miocene benthic foraminiferal and abyssal circulation changes in the North Atlantic. Micropaleontology, 33:97149.
Miller, K.G., Katz, M.E., and Berggren, W.A., 1992. Cenozoic deep-sea benthic foraminifera: a tale of three turnovers. In BENTHOS ' 90 : Sendai (Tokai Univ. Press), 67-75.

Miller, K.G., and Lohmann, G.P., 1982. Environmental distribution of Recent benthic foraminifera on the northeast United States continental slope. Geol. Soc. Am. Bull., 93:200-206.

Miller, K.G., and Mountain, G.S., 1994. Global sea-level change and the New Jersey margin. In Mountain, G.S., Miller, K.G., Blum, P., et al., Proc. ODP, Init. Repts., 150: College Station, TX (Ocean Drilling Program), 11-20.

Miller, K.G., Wright, J.D., and Fairbanks, R.G., 1991. Unlocking the ice house: Oligocene-Miocene oxygen isotopes, eustasy, and margin erosion. J. Geophys. Res., 96:6829-6848.

Mountain, G.S., Miller, K.G., Blum, P., et al., 1994. Proc. ODP, Init. Repts., 150: College Station, TX (Ocean Drilling Program).

Natland, M.L., 1933. The temperature and depth distribution of some Recent and fossil foraminifera in the southern California region. Scripps Inst. Oceanogr. Tech. Ser, 3:225-230.

Olsson, R.K., Melillo, A.J., and Schreiber, B.L., 1987. Miocene sea level events in the Maryland coastal plain and the offshore Baltimore Canyon trough. In Ross, C., and Haman, D. (Eds.), Timing and Depositional History of Eustatic Sequences: Constraints on Seismic Stratigraphy. Spec. Publ. Cushman Found. Foraminiferal Res., 24:85-97.

Olsson, R.K., Miller, K.G., and Ungrady, T.E., 1980. Late Oligocene transgression of middle Atlantic coastal plain. Geology, 8:549-554.

Poag, C.W., 1978. Neogene stratigraphy of the submerged U.S. Atlantic margin. Palaeogeogr., Palaeoclimatol., Palaeoecol., 47:103-127.

, 1985. Depositional history and stratigraphic reference section for central Baltimore Canyon trough. In Poag, C.W. (Ed.), Geologic Evolution of the United States Atlantic Margin: New York (Van Nostrand Reinhold), 217-263.

Poag, C.W., Watts, A.B, et al., 1987. Init. Repts. DSDP, 95: Washington (U.S. Govt. Printing Office).

Posamentier, H.W., Jervey, M.T., and Vail, P.R., 1988. Eustatic controls on clastic deposition, I. Conceptual framework. In Wilgus, C.K., Hastings, B.S., Ross, C.A., Posamentier, H.W., Van Wagoner, J., and Kendall, C.G.St.C. (Eds.), Sea-Level Changes: An Integrated Approach. Spec. Publ. Soc. Econ. Paleontol. Mineral., 42:109-124.

Schröder, C.J., Scott, D.B., and Medioli, F.S., 1987. Can smaller benthic foraminifera be ignored in paleoenvironmental analyses? J. Foraminiferal Res., 17:101-105.

Shackleton, N.J., and Kennett, J.P., 1975. Paleotemperature history of the Cenozoic and the initiation of Antarctic glaciation: oxygen and carbon isotope analyses in DSDP Sites 277, 279, and 281. In Kennett, J.P., Houtz, R.E., et al., Init. Repts. DSDP, 29: Washington (U.S. Govt. Printing Office), 743-755.

Steckler, M.S., and Watts, A.B., 1982. Subsidence history and tectonic evolution of Atlantic-type continental margins. In Scrutton, R.A. (Ed.), Dynamics of Passive Margins. AGU Geodyn. Ser., 6:184-196.

Steckler, M.S., Watts, A.B., and Thorne, J.A., 1988. Subsidence and basin modeling at the U.S. Atlantic passive margin. In Sheridan, R.E., and Grow, J.A. (Eds.), The Geology of North America (Vol. 2): The Atlantic Continental Margin. Geol. Soc. Am., 399-416.

Streeter, S.S., 1973. Bottom water and benthonic foraminifera in the North Atlantic: glacial-interglacial contrasts. Quat. Res., 3:131-141.

Streeter, S.S., and Lavery, S.A., 1982. Holocene and latest glacial benthic foraminifera from the slope and rise off eastern North America. Geol. Soc. Am. Bull., 93:190-199.

Thomas, E., 1990. Late Cretaceous through Neogene deep-sea benthic foraminifers (Maud Rise, Weddell Sea, Antarctica). In Barker, P.F., Kennett, J.P., et al., Proc. ODP, Sci. Results, 113: College Station, TX (Ocean Drilling Program), 571-594.

1992a. Middle Eocene-late Oligocene bathyal benthic foraminifera (Weddell Sea): faunal changes and implications for ocean circulation. In Prothero, D.R., and Berggren, W.A. (Eds.), Eocene-Oligocene Climatic and Biotic Evolution: Princeton (Princeton Univ. Press), 245271.

1992b. Cenozoic deep-sea circulation: evidence from deep-sea benthic foraminifera. In Kennett, J.P., and Warnke, D. (Eds.), The Antarctic Paleoenvironment: A Perspective on Global Change. Am. Geophys. Union, Antarct. Res. Ser., 56:141-165.

Thomas, E., Booth, L., Maslin, M., and Shackleton, N.J., 1995. Northeastern Atlantic foraminifera during the last 45,000 yrs.: changes in productivity as seen from the bottom up. Paleoceanography, 10:545-562. 
Thomas, E., and Vincent, E., 1987. Equatorial Pacific deep-sea benthic foraminifera: faunal changes before the middle Miocene polar cooling. Geology, 15:1035-1039.

Tjalsma, R.C., 1983. Eocene to Miocene benthic foraminifers from DSDP Site 516, Rio Grande Rise, South Atlantic. In Barker, P.F., Carlson, R.L., Johnson, D.A., et al., Init. Repts. DSDP, 72: Washington (U.S. Govt. Printing Office), 731-756.

Tjalsma, R.C., and Lohmann, G.P., 1983. Paleocene-Eocene bathyal and abyssal benthic foraminifera from the Atlantic Ocean. Micropaleontol. Spec. Publ., 4.

Tucholke, B.E., and Mountain, G.S., 1979. Seismic stratigraphy, lithostratigraphy, and paleosedimentation patterns in the North American basin. In Talwani, M., Hay, W., and Ryan, W. (Eds.), Deep Drilling Results in the
Atlantic Ocean: Continental Margins and Paleoenvironment. Am. Geophys. Union, Maurice Ewing Ser., 3:58-86.

van Hinte, J.A., Wise, S.W., Jr., et al., 1987. Init. Repts. DSDP, 93: Washington (U.S. Govt. Printing Office).

van Morkhoven, F.P.C.M., Berggren, W.A., and Edwards, A.S., 1986. Cenozoic cosmopolitan deep-water benthic foraminifera. Bull. Cent. Rech. Explor.-Prod. Elf-Aquitaine, Mem. 11.

Woodruff, F., and Savin, S.M., 1989. Miocene deepwater oceanography. Paleoceanography, 4:87-140.

Date of initial receipt: 6 March 1995

Date of acceptance: 26 July 1995

Ms 150SR-003

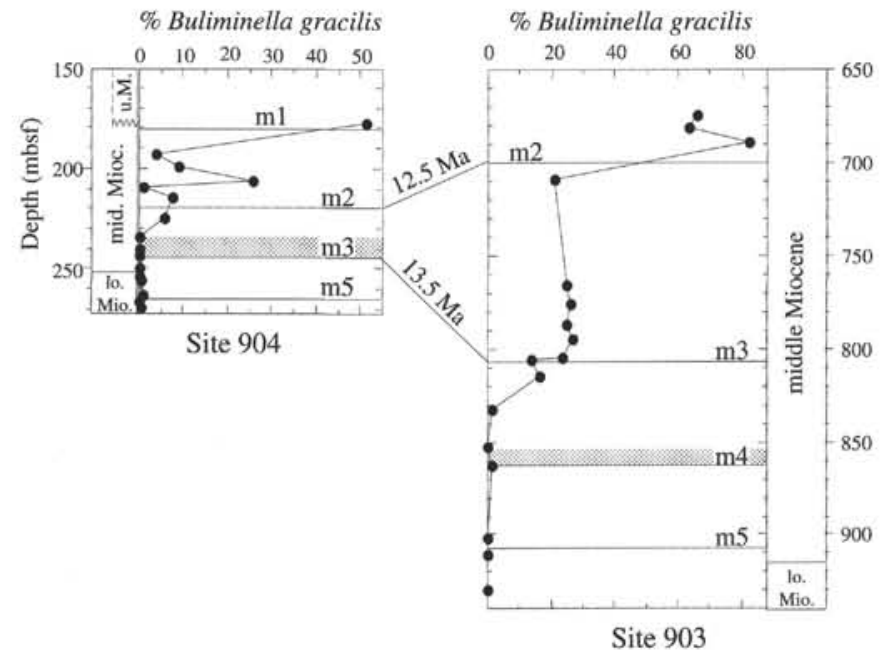

Figure 15. Percentage of Buliminella gracilis as a shelf transport proxy. At Sites 903 and 904, abundant downslope transport is indicated by the increase upsection of percentage $B$. gracilis between Reflectors $\mathrm{m} 3$ and $\mathrm{m} 2$.

\section{APPENDIX}

Taxonomic List for This Study

Abyssamina quadrata Schnitker and Tjalsma Alabamina dissonata (Cushman and Renz) Alabamina wilcoxensis Toulmin

Alabamina sp.

Allomorphina paleocenica Cushman

Ammodiscus sp.

Amphicoryna ignota Cushman and Siegfus

Angulogerina illingi Cushman and Renz

Anomalinoides aragonensis (Nuttall)

Anomalinoides capitatus (Gumbel)

Anomalinoides pseudogrosserugosus Colom

Anomalinoides semicribratus (Beckmann)

Anomalinoides spissiformis (Cushman and Stainforth)

Anomalinoides sp. 904

Anomalinoides spp.

Aragonia aragonensis (Nuttall)

Arenobulimina truncata (Reuss)

Astacolus spp.

Astrononion sp.

Baculogypsina sp.

Bigenerina sp.

Bolivina advena Cushman

Bolivina antegressa Subbotina

Bolivina furcata Cushman and Jarvis

Bolivina huneri Howe

Bolivina spp.

Bulimina aculeata d'Orbigny

Bulimina alazanensis Cushman
Bulimina bradbury Martin

Bulimina callahani Galloway and Morrey

Bulimina glomarchallengeri Tjalsma and Lohmann

Bulimina impendens Parker and Bermúdez

Bulimina jacksonensis Cushman

Bulimina macilenta Cushman and Parker

Bulimina mexicana Cushman

Bulimina semicostata Nuttall

Bulimina cf. semicostata

Bulimina subtruncana Hagn

Bulimina trinitatensis Cushman and Jarvis

Bulimina tuxpamensis Cole

Bulimina sp. X

Bulimina sp. A

Bulimina spp.

Buliminella gracilis Cushman

Buliminella grata Parker and Bermúdez

Cassidulina crassa d'Orbigny

Cassidulina havanensis (Cushman and Bermúdez)

Cassidulina laevigata d'Orbigny

Cassidulina spp.

Cassidulinoides spp.

Ceratobulimina sp.

Chilostomella sp.

Chilostomellina sp.

Chrysalogonium spp.

Cibicidoides bradyi (Trauth)

Cibicidoides cookei (Cushman and Garrett)

Cibicidoides crebbsi (Hedberg)

Cibicidoides dickersoni (Bermúdez)

Cibicidoides dohmi Bermúdez 
Cibicidoides eocaenus (Gümbel)

Cibicidoides eocaenus/praemundulus intergrade

Cibicidoides grimsdalei (Nuttall)

Cibicidoides grosseperforatus van Morkhoven and Berggren

Cibicidoides haitiensis (Coryell and Rivero)

Cibicidoides havanensis (Cushman and Bermúdez)

Cibicidoides havanensis/praemundulus intergrade

Cibicidoides laurisae (Mallory)

Cibicidoides micrus Bermúdez

Cibicidoides mundulus (Brady, Parker, and Jones)

Cibicidoides aff. mundulus

Cibicidoides osangularis

Cibicidoides pachyderma (Rzehak)

Cibicidoides perlucidus (Nuttall)

Cibicidoides popeliensis Myatlyuk

Cibicidoides praemundulus Berggren and Miller

Cibicidoides aff. praemundulus

Cibicidoides? praemundulus

Cibicidoides robertsonianus (Brady)

Cibicidoides subhaidingerii (Parr)

Cibicidoides subspiratus (Nuttall)

Cibicidoides sp. A

Cibicidoides sp. C

Cibicidoides sp. 13

Cibicidoides spp.

Clinapertina complanata Tjalsma and Lohmann

Clinapertina inflata Tjalsma and Lohmann

Cyclammina sp.

Dentalina spp.

Dorothia trochoides (Marsson)

Dorothia spp.

Eggerella bradyi (Cushman)

Eggerella spp.

Ehrenbergina serrata Reuss var. gibbera Galloway and Heminway

Favocassidulina sp.

Fissurina spp.

Fursenkoina makiyamai (Chiji)

Fursenkoina sp.

Gaudryina spp.

Globobulimina notovata

Globobulimina spp.

Globocassidulina punctata Berggren and Miller

Globocassidulina subglobosa (Brady)

Gyroidinoides sp. A

Gyroidinoides sp. 1

Gyroidinoides spp.

Hanzawaia ammophila (Gümbel)

Hanzawaia mantaensis (Galloway and Morrey)

Hanzawaia spp.

Hoeglundina elegans (d'Orbigny)

Hopkinsina sp.

Karreriella chapapotensis (Cole)

Karreriella chapapotensis (Cole) var. monumentensis Mallory

Karreriella cubensis Cushman and Bermúdez

Karreriella subglabra (Guembel)

Karreriella sp. A

Karreriella spp.

Lagena spp.

Laticarinina pauperata (Parker and Jones)

Lenticulina peregrina (Schwager)

Lenticulina sp. A

Lenticulina spp.

Lenticulinids

Loxostomoides $\mathrm{cf}$. applinae

Loxostomoides sp.

Loxostomum spp.

Marginulina hirsuta (d'Orbigny)

Marginulina spp.

Marginulinids

Martinottiella communis (d'Orbigny)

Martinottiella spp.

Massilina decorata Cushman

Matanzia sp.

Melonis barleeanum (Williamson)
Melonis pompilioides (Fichtel and Moll)

Melonis spp.

Nodosarella spp.

Nonion havanense Cushman and Bermúdez

Nonion sp.

Nonionella pizarrensis

Nonionella spp.

Nonionellina spp.

Nuttallides truempyi (Nuttall)

Nuttallides spp.

Nuttallinella florealis (White)

Oolina spp.

Oridorsalis spp.

Orthomorphina spp.

Osangularia spp.

Pararotalia sp.

Paratrochamminoides challengeri Bronnimann and Whittaker

Planulina ambigua (Franzenau)

Planulina aff. ambigua

Planulina costata (Hantken)

Planulina renzi Cushman and Stainforth

Planulina sp. A

Planulina spp.

Planulina wuellerstorfi (Schwager)

Plectina elongata Cushman and Bermúdez

Plectina nuttalli Cushman and Stainforth

Plectina sp.

Plectofrondicularia kerni Cook

Plectofrondicularia sp. A

Plectofrondicularia sp. Z

Plectofrondicularia spp.

Pleurostomella spp.

Pleurostomellids

Polymorphinids

Praeglobobulimina spinescens Brady

Pseudonodosaria spp.

Pullenia bulloides (d'Orbigny)

Pullenia eocenica Cushman and Siegfus

Pullenia quinqueloba (Reuss)

Pullenia spp.

Quadratobuliminella pyramidalis de Klasz

Quinqueloculina spp.

Rectuvigerina multicostata (Cushman and Jarvis)

Rectuvigerina senni (Cushman and Renz)

Rectuvigerina stonei (Bermúdez)

Rectuvigerina vesca (Finlay)

Saracenaria spp.

Sigmoilopsis schlumbergeri (Silvestri)

Sigmoilopsis spp.

Siphonina sp.

Siphonina tenuicarinata Cushman

Siphotextularia sp.

Sphaeroidina bulloides d'Orbigny

Spiroloculina spp.

Spiroplectammina spectabilis (Grzybowski)

Spirosigmoilina tenuis (Czjzek)

Spirosigmoilina sp.

Stilostomella aculeata (Cushman and Renz)

Stilostomella aculeata/subspinosa intergrade

Stilostomella curvatura (Cushman)

Stilostomella gracillima (Cushman and Jarvis)

Stilostomella lepidula (Schwager)

Stilostomella modesta (Bermúdez)

Stilostomella nuttalli (Cushman and Jarvis)

Stilostomella paucistriata (Galloway and Morrey)

Stilostomella subspinosa (Cushman)

Stilostomella sp. C

Stilostomella spp.

Textularia spp.

Trifarina bradyi Cushman

Trifarina danvillensis (Howe and Wallace)

Trifarina sp. X

Trifarina sp. Y

Trifarina sp. 2 
Tritaxia havanensis (Cushman and Bermúdez) Tritaxia paleocenica Tjalsma and Lohmann

Tritaxia spp.

Turrilina robertsi (Howe and Ellis)

Uvigerina adelinensis Palmer and Bermúdez

Uvigerina auberiana d'Orbigny

Uvigerina aubertae Boersma

Uvigerina carapitana Hedberg

Uvigerina chirana Cushman and Stone

Uvigerina cocoensis Cushman

Uvigerina elongata Cole

Uvigerina havanensis Cushman and Bermúdez

Uvigerina hispida Schwager
Uvigerina mexicana Nuttall

Uvigerina pigmea d'Orbigny

Uvigerina proboscidea Schwager

Uvigerina? proboscidea

Uvigerina spinulosa Hadley

Uvigerina sp. A

Uvigerina spp.

Vaginulina sp.

Vaginulinopsis baggi McLean

Vaginulinopsis spp.

Virgulina sp.

Vulvulina spinosa Cushman

Vulvulina spp. 